\title{
Russian Internet Censorship and Its Future Perspectives in Comparative Context
}

Joshua Baker

West Virginia University

Follow this and additional works at: https://researchrepository.wvu.edu/etd

\section{Recommended Citation}

Baker, Joshua, "Russian Internet Censorship and Its Future Perspectives in Comparative Context" (2011). Graduate Theses, Dissertations, and Problem Reports. 726.

https://researchrepository.wvu.edu/etd/726

This Thesis is protected by copyright and/or related rights. It has been brought to you by the The Research Repository @ WVU with permission from the rights-holder(s). You are free to use this Thesis in any way that is permitted by the copyright and related rights legislation that applies to your use. For other uses you must obtain permission from the rights-holder(s) directly, unless additional rights are indicated by a Creative Commons license in the record and/ or on the work itself. This Thesis has been accepted for inclusion in WVU Graduate Theses, Dissertations, and Problem Reports collection by an authorized administrator of The Research Repository @ WVU. For more information, please contact researchrepository@mail.wvu.edu. 


\title{
Russian Internet Censorship and Its Future Perspectives in Comparative Context
}

\author{
Joshua Baker \\ Thesis submitted to the \\ Eberly College of Arts and Sciences \\ at West Virginia University \\ in partial fulfillment of the requirements \\ for the degree of
}
Master of Arts
in
History

\author{
Robert Blobaum Ph.D., Chair \\ Mark Tauger Ph.D. \\ Elizabeth Fones-Wolf Ph.D. \\ Department of History
}

\section{Morgantown, West Virginia \\ 2011}

Keywords: Censorship; Media Control; Russian Policy; Internet; Comparative Copyright 2011 John H. Hagen 


\title{
ABSTRACT \\ Russian Internet Censorship and Its Future Perspectives in Comparative Context
}

\begin{abstract}
Joshua Baker
The purpose of this work is to provide an analysis of the contemporary state of the Russian internet in regards to both the freedom of information within it and the government's influence over it. This project also examines the potential state of that situation in the coming years. Public statements, government actions, and media interactions with the government were analyzed in an effort to find trends relating to the government's influence over the media since the collapse of the Soviet Union. These trends show an increased tightening of the Kremlin's control over the media (especially since the rise to power of Vladimir Putin) as well as a pattern of the government undercutting its own statements about speech protection with its actions. In addition, an examination of the strategies and tools utilized by the United States and China in regard to the internet was conducted in order to determine the options available to the Russian government. This was also done to find shared practices and ways that they might further evolve in the future. The Kremlin has both publicly stated and inferred its desire to look into the practices of these states. Both the U.S. and China have shown their ability to intimidate organizations and businesses in an effort to influence internet content, and have enhanced their legal ability to control it. They also utilize technical means to filter content and disrupt websites and use their influence to coerce individuals into self-censorship. The findings, including leaked government documents and interviews, provide a basis for concluding that the Russian government has greatly tightened its grip over the internet in recent years. This analysis also suggests governmental controls over the internet will only increase as the amount of Russian internet users continues to grow (as projections show it will).
\end{abstract}




\section{Table of Contents}

$\begin{array}{lr}\text { Introduction } & 1\end{array}$

Chapter 1 - The Times They Are A Changin' 4

Changes in Government Influence Over the Media after

the Dissolution of the Soviet Union

Chapter 2 - Comparisons in Controlling

International Strategies Regarding Internet Control

Chapter 3 - Signal of the Coming Storm

48

The Kremlin's Handling of the Internet

Conclusions

60

Bibliography

62 


\section{$\underline{\text { Russian Internet Censorship and Its Future Perspectives in Comparative Context }}$}

"It's possible to go on to the Internet and get basically anything you want. In that regard, there are no problems of closed access to information in Russia today, there weren't any yesterday and there won't be any tomorrow," - Russian President Dmitry Medvedev (Baldwin).

Following the dissolution of the Soviet Union there has been a general feeling that the "old media" in Russia is in the Kremlin's pocket, mainly because of the close relationship that the

government has with many of the owners and ownership groups that are running television stations and newspapers, but also because of the tactics that the government led by Vladimir Putin has used in order to intimidate and coerce those that were not aligned with the Kremlin.

There was a general consensus, however, due in large part to the statements from President Medvedev and Prime Minister Putin concerning the internet as a medium open to free communication and necessary as part of a free flowing exchange of ideas, that unlike traditional media, the internet would be a safe haven of sorts for independent thought and speech.

While there was a point when the internet in Russia was free from government influence, it appears that there will be more and more government influence on the internet in the future. The Kremlin has realized that there is an ever growing number of its citizens (especially its young citizens) who receive the majority of their news and general information from the internet and not from the "Old Media" influenced by the government. Polling data conducted over the last ten years show that in 2001 only $7 \%$ of the Russian population could be considered internet-users of any degree (Russianvotes 1). By September 2010, that figure had skyrocketed to $43 \%$ of the population and estimates predict that by 2015 internet use will embrace more than $60 \%$ of the population. In fact, Russian President Medvedev 
has said that he expects that proportion to climb to around $90 \%$ in the next "several years" ("At Least 90 Percent of Russians").

The growing number of internet users in Russia has persuaded and will continue to persuade the state to take more concerted action in regards to the internet. Looking at the development of government influence on the media in the past twenty years since the fall of the Soviet Union one can see, especially since the Putin era began, a state that has few problems with heavily influencing the message that is delivered through the media.

This study will look at other states' strategies in regards to government influence on the internet to get a better understanding of the situation that Russia finds itself in. In particular, this thesis will make comparisons with the United States, due to the fact as a superpower like Russia, it has certain protections afforded to freedom of speech, but works around those protections in order to influence the media. I will also be looking at the ways that the United States government is able to apply pressure on corporations in order to dissuade them from forming relationships with media outlets that unveil information that the government would prefer hidden. Finally, I will examine the government's attempts to manipulate US laws in order to put pressure on individuals and to promote self censorship.

This study will also make comparisons with China to see the options that are available for a state that makes no qualms about the filtering of content that it allows into the information stream. This is especially relevant to this work, given the recent announcement by the Russian government that it will be taking a closer look at the methods of internet regulation employed by the Chinese government and to potentially adopt some of its techniques. In addition to the technical aspects of the Chinese Firewall that the Russian government has recently been looking into, I will also look at ways that Chinese government has been able to use a more "low-fi" strategy of incarceration and coercion to act as a means of prevention.

In looking at Russia's post-Soviet experience, this study will emphasize how the Kremlin's 
relationship with traditional media (along with the government's public statements in regards to media) has evolved. In examining the ways in which the Kremlin has emulated the United States and China in its handling of content on the internet, I will attempt to make predictions based on trends and patterns, both in Russia's own practices and in those that it may adopt for Russian use. It is my goal to argue that in the coming years, despite popular opinion to the contrary, the Russian government will (through technology and intimidation) enact a thorough measure of censorship on the Russian internet. 


\section{The Times They Are A Changin'}

Changes in Government Influence over the Media after the Dissolution of the Soviet Union.

The changes that have been made regarding the Russian media are unlike those anywhere else on the planet. The changes have been both abrupt and gradual, radical and expected. In order to understand the situation that is currently facing the Russian internet it is necessary for us to view it not as an individual moment isolated in time, but rather part of a larger picture that can better be seen when one steps back and looks at Russia since the fall of the Soviet Union twenty years ago and to take into account measures that were taken at the time of the USSR's collapse.

To begin, it is necessary to take a brief look at the Soviet Union's policy of Glasnost under Mikhail Gorbachev. Before the policy of Glasnost strong state censorship throughout the USSR kept the Soviet media under control. Glasnost was a program of "openness" brought about by Gorbachev as an attempt to create transparency in the bureaucracy that was so heavily prevalent within the Soviet Union. Gorbachev said in a speech in December of 1984 that the Soviet citizen was a person who "won't accept simplistic answers to questions, and keenly senses the falsehoods produced by an inability or fear to reveal the real contradictions of socialist development... To that person, we are bound to speak only the truth" (McNair Glasnost 43). Gorbachev continued to discuss in his speech that the 'truth' is:

an integral aspect of socialist democracy and a norm of all public life. Extensive, timely and candid information is an indication of trust in people and of respect for their intelligence, feelings and ability to comprehend various events on their own... Glasnost in the work of Party and state agencies is an effective means of combating bureaucratic distortions and obliges people to take a more thoughtful approach to... the rectification of shortcomings and deficiencies. In large part the persuasiveness of propaganda... depends on this... (McNair Glasnost 44).

Judging by this statement alone the Glasnost program that Gorbachev would introduce would seem to 
be the dawning of a new era in public discourse for the Soviet Union (and, in turn, Russia). It may also seem to be a signal of freedom of speech and freedom of the press. Is this what Gorbachev had in mind when he was creating this policy? Not necessarily. There are those like then Russian dissident Zhores Medvedev who said that the policy was rather ambiguous and implied that it was perhaps misleading in the way that it appeared as a policy of freedom of information but was actually a policy about the distribution of certain information. Medvedev stated that Glasnost was "rather ambiguous. It conveys the idea of publicity rather than of frankness. The publication of selective reports about weekly Politburo meetings is an example of Glasnost, but the very fact that the reports are selective and brief show the limits of the meaning and how far it is from open government" (Gibbs 48).

It can certainly be argued that Glasnost, instead of a policy about the universal dispersal of information and the dissemination of facts throughout the Soviet Union in order to provide for a more knowledgeable citizenship, was in fact a two-fold weapon of public relations. The state would be able to shape public opinion by being able to get ahead of and craft the story by controlling what information was released and molding the public knowledge base, but also claim that it had adopted a policy about the universal dispersal of information. Even Pravda, essentially a mouthpiece for the Communist Party, said that Glasnost was "a powerful weapon of restructuring" (Gibbs 13). That said, Glasnost should certainly be viewed, by any who supports the idea of freedom of expression, thought, or speech, as a positive point in world history because it was the starting point of all the events that would follow concerning Russian media. As Gorbachev said himself, "Glasnost broke out of the limits that we had initially tried to frame and became a process that was beyond anybody's control" (Gibbs 13). It should also be pointed out that during this period of time the Soviet government also drastically reduced the responsibilities of Glavlit, the censorship organ of the Soviet Union. Former editor of Pravda and the former Glavlit director, Vladimir A. Bolyrev said that there was a scaling back of the tasks assigned to Glavlit during the last half of the 80s. He said that, "Since $1986 \ldots$ censorship in its 
generally accepted concept here as a control over brains and ideas has ceased to exist" (Goldstein).

Glavlit went from a statewide censorship agency to an organization that was monitoring mail that entered the Soviet Union, though at more relaxed levels than during the peak of its censorship responsibilities. It was also still monitoring content dealing with defense, foreign affairs, and national security (Lipset 23). According to Bolyrev August 1, 1990 can "officially be considered the day of the 'demise' of Glavlit as censorship" ("No Censorship" 9).

Regardless of the intent of Glasnost it is undoubtable that its effects were dramatic and cannot be overlooked. The policy, whether in and of itself a policy promoting freedom of information, or just a stepping stone to get there, "is still regarded within Russian society as one of its most precious achievements, and the vast majority of people aren't willing to accept any kind of change to it," as stated by the Council of Europe's Commissioner for Human Rights on his visit to Russia (Gil-Robles).

Glasnost helped Russia to become a state where speech and the right to information are both protected, but it was still just a part of that progression. Another major step took place in 1990. In the 1980s, while political pressures on media outlets began to lighten, there was still nothing protecting them from the influence of or censorship by the government. Glasnost was just a policy and did not come with any sort of legal protections against state interference. That changed when Gorbachev signed the Soviet Law on the Press and Other Mass Information Media. The law was designed to limit censorship, which had been so prevalent throughout the history of the Soviet Union, to state security matters and provided considerable autonomy for the editorial staffs of various media outlets. The law was defined by Yelena Rodnevskaya, the head of the Russian Ministry of the Press and Information's Department for the Development of Information Policy, as follows: "Law [on the Press] gives every citizen the right to publish his own magazine. A painful structural reorganization of the periodical press has begun. The spectrum of publishing is expanding, and niches that used to be empty and unrecognized are being filled. What's more, the time in which we live is not a 'silver age' but rather an 
age of mass culture" (Rubansteva 32). The law was the first legal act "in the history of the Soviet state" which contained detailed guarantees of the freedom of the press and of rights that protected journalists, beyond what had been "merely declared in the USSR Constitution" (LA Times). The law was designed to regulate the procedure for setting up mass media and their relations with the state and citizens; it also did the same with the relations between the founder, publisher, and editors. The law provided that "the right to establish mass media belongs not only to state and public organizations, political parties, and various associations but also to any citizen of the USSR who has reached the age of 18 " (LA Times). There were many heated debates that were caused by this clause in particular, especially in the drafting of the bill, but it goes without saying that "the right to establish a press organ was one of the most important democratic freedoms recorded in international human rights agreements to which the Soviet Union [was] a party" (LA Times).

Beyond just granting every citizen of the Soviet Union over the age of 18 the right to establish a press organ, the law protected media outlets against censorship, stating "censorship of the mass media is impermissible," which was indeed a revolutionary concept for the once secretive and censoring Soviet government. The law also declared "after months of debate" that "the press and other mass media are free" (LA Times). This concept was further elaborated by the deputy chariman of the parliamentary Committee for Glasnost, Boris Nikolskiy, who explained that the responsibility for disclosing secret information needed to rest with the individuals or organizations that had allowed it to leak in the first place, and should not be a burden which the mass media needed to bear. In other words, it was not the media's responsibility, any longer, to act as a mouthpiece for the Soviet government and it was certainly not their responsibility to keep mouths shut. In addition to providing protections for the media, the law also stated the consequences and punishments for those individuals who impede the "lawful professional activity of journalists" and also for inciting "them towards distributing or refusing to distribute information." It provided journalists with the right to "refuse to 
prepare material which runs counter to his convictions and also to remove his signature from material, the content of which has been distorted during the editorial preparations" (The Criminal Code). In addition to this right it also provided Soviet journalists the "right to attend meetings and be present at the scene of disasters" and the "right to hold interviews with officials" (The Criminal Code). This law was a monumental change for the journalists of the Soviet Union. It is important to keep in mind the path that was taken to get to just that point, the changes that evolved as far as media censorship was concerned, and the manner in which they took place. Subtle, slow changes, yet they were also shaped by large, ground-breaking policies and laws that shook the very existence of the Soviet Union.

This new and free media culture was threatened very early on in its existence in the form of the short-lived August coup. The conspirators created the State Committee of the State of Emergency, or the Gosudarstvenniy Komitet po Chrezvichaynomu Polozheniyu. The GKChP quickly re-instituted political censorship over the media by banning all newspapers from the city of Moscow except for a select nine which were state-controlled. The coup was unsuccessful in so far as its conspirators were unable to seize power; however, it certainly shook things up in the communist party, and the Soviet Union as a whole. After the failure of the coup the temporary political censorship that its leaders imposed was also eliminated and the Mass Media law was again in effect. Shortly thereafter the Soviet Union began to disintegrate.

Following the fall of the Soviet Union it did not take long for the post-Soviet Russian media to have their first major event, which took place almost immediately after the collapse. On the $27^{\text {th }}$ of December, 1991, a new media law was signed into existence by the President of the Russian Federation, Boris Yeltsin, having already been passed by the then Russian parliament. Due to the fact that it was constructed by mainly the same authors who drafted the earlier Mass Media law during the last year of the Soviet Union, this new law was by and large very similar to its predecessor. It "provide[d] for the registration of newspapers or broadcasting media, although with a right of appeal to 
the courts if registration is refused." It was also designed to "forbid [the] censorship or the establishment or financing of any censorship agency," though it made clear that there were "certain specific limits on free expression: forbidding in particular the disclosure of state secrets, the incitement of national, religious or class intolerance, incitement to overthrow the existing system by force and the use of the media for the committing of criminally punishable acts" (Benn 473). These statements ran slightly contradictory to the ideas of the former deputy chariman of the parliamentary Committee for Glasnost, Boris Nikolskiy, when he said that the responsibility for maintaining state secrets laid with those who initially possessed them and with those who allowed them to become publicly known, not with the media. However, not much attention has been paid to this part of the law due to the fact that this is a relatively common practice among many governments. That said, it is still something that is noteworthy and can be viewed as a potential legal loop hole. There are also provisions within the law to restrict the "dissemination of 'erotic' material" (Benn 473). Most states also have legal provisions like this regarding the media, which are often viewed as a way to protect minors from pornographic content that some feel could prove harmful to their development. Another important portion of this law to note is the fact that it states clearly that the "closing down of any media outlet except by order of a court after due warning" is expressly and explicitly forbidden (Benn 473). This law in nearly every conceivable manner established at the very least freedoms and protections equal to those of its predecessor, the Soviet Mass Media law of 1990. Also of importance is the fact that the establishment of a Federal Commission for Television and Radio is included in this law, which also grants the government power to award broadcasting licenses to those looking to distribute news or their message (Benn 473).

Now, this is not to say that in short time between the signing of the Soviet media law and its replacement by the Russian media law that all media was safe and free from constraints or limitations. After all, the 1990 law was the first time that protections for the freedom of expression even existed in 
Soviet Russia. It can be said that these laws were victories for an independent press and its supporters, but they were by no means the final outcome in the proverbial war. Despite the existence of these laws, some reporters said that "the battle for media freedom has certainly not been lost; nor has it yet been decisively won" (Benn 473). The realities of the situation were, as they always are - especially, it seems in regards to Russia- a lot more gray than they were black and white.

Throughout the years following the passing of the media law, there were instances when the media and press of the Russian Federation were praised for their open and honest work by revealing information and uncovering stories that most likely would not have been known at all internationally or if they were, only by murky details barely revealed - if the old Soviet system of censored media was still in place. That said, there were instances when many were left to wonder just how free the Russian media truly were, despite all the praise and pronouncements made about the end of censorship.

The years immediately following the dissolution of the Soviet Union also saw the Russian Federation mired in an era of constitutional and political contention. The need for an official Constitution loomed large over Russian politics but was held up by the inability of the parliament to agree on a "solid and uncontroversial" draft of the Constitution. This led to Yeltsin publicly voicing his displeasure with the legislative branch and attempting to circumvent its involvement in the process by having a national referendum to be followed by a Congressional Assembly (Andrews 26). This caused opponents of Yeltsin to call into question the reach of his authority and Yeltsin then issued Presidential Decree 1400, which disbanded the parliament, to great shouts of protest from many in parliament who barricaded themselves within the parliament building and elected Yeltsin's Vice-President Alexander Rutskoi to the office of President. Rutskoi's term was short-lived as the army, under Yeltsin's orders, fired upon the parliament and forced the surrender of those members of parliament, including parliament leader Ruslan Khasbulatov, who was taken into custody. Despite the violent end of this conflict there were many incidents of media manipulation and control that took place over the span of 
the Constitutional crisis (Andrews 15).

An example of such control is seen in the television media during the run up to the spring referendum of April 25, 1993. There was a groundswell of support, especially among Russian liberals, for Yeltsin and a pro-government feeling in general during this time (Erlanger). This pro-government feeling seemed to characterize the media at the time, demonstrated over the course of that year in the “obtrusive partisanship of state television" during the build up to the legislative elections of 1993 (Swanson and Mancini 119). This bias in the media could be strongly felt particularly following September 1993 when, almost immediately after the dissolution of the old Russian parliament the daily television show "Parliamentary Hour," which had provided Yeltsin's opposition with an outlet to express grievances, was taken off the air. Suddenly a media source, television, from which a sizable percentage of Russian citizens received their news no longer had even a semblance of balance between the government and the political opposition. This, however, could also be interpreted as simply a matter of a television show being canceled, which despite the fact that it provided the opposition's viewpoint, is a fairly common occurrence. However, it should be kept in mind that while television shows get canceled regularly "Parliamentary Hour" was not a normal show on commercial television but a program that was broadcast on the state-controlled Channel Two and had the specific purpose of providing opposing voices to Yeltsin the chance to express their points of view (Mickiewicz 122).

What was not a common occurrence was the blatant disregard for the much-praised Media Law of 1991 which took place approximately a month after the dissolution of the Russian parliament. President Yeltsin signified his supreme authority by "suspending a range of political movements and closing opposition newspapers" (Steele and Hearst). This was a move that was in direct violation of the Media Law of 1991 which stated that this was a power that was only vested within the judicial branch of the Russian Government. Two of the banned newspapers, Sovetskaya Rossiya and Pravda, had been informed that they needed to be re-registered in order to begin publishing content again, something that 
was also in direct violation of the post-Soviet law (Basok and Benitard 5). The newspapers took their cases to court where they both eventually were found to be in the right and were allowed to continue publication. However, due to the timing of the matter both newspapers were effectively banned from participating in or having any sort of influence over the elections with Pravda reappearing only on the $10^{\text {th }}$ of December and Sovetskaya Rossiaya not returning until after the legislative elections were over. There is no doubt that the government officials who were responsible for the initial banning of the newspapers were well aware of the timing of their suspension. This was just one early example of the State returning back to its old ways of intimidation and control.

From the $21^{\text {st }}$ of November until the $13^{\text {th }}$ of December, 1993, the European Institute for the Media (EIM) in Dusseldorf became involved in monitoring the Russian media during the time of the elections, with eight observers going to seven different locations (Colton and Haugh 226). Now, this is not to say that the only candidates who were given airtime were those that were supported by the government, but the numbers were staggeringly in the favor of those who had the blessing of the Kremlin. In the aforementioned investigation conducted by the EIM it was decided that there was a drastically skewed amount of airtime that went to those candidates who were supported by Yeltsin. A strong example of this was with Vladimir Zhirinovsky who reportedly received significantly less exposure than his opponents. In fact, Yeltsin's party, Russia's Choice, "received more than double the amount of exposure in paid and editorial time than the next most exposed party" which wasn't Zhirinovsky's party but rather a third one (Light and Rich 42). The investigation by EIM also determined that "pressure, particularly with regard to the draft Constitution, was directly and indirectly applied by the government on all media" and that there was a significant bias among the media in the way that they presented information concerning the Constitution and that the "editorial coverage was deeply flawed" (Benn 473). This can help explain the low numbers of popular support that the parliament were experiencing during the referendum (which coincided with high popularity for Yeltsin 
at the same time). This lead to Khasbulatov to claim that the media was using "information terror" to attack and discredit both the legislature and himself (Andrews 64).

However, as can be expected in a situation in which a state that had practiced censorship for nearly its entire existence finally allows freedom of the press, there were conflicting examples of the ability of the press to succeed in this situation and of the ability of the government to be contained by the laws which it created to protect the media. While there were examples of the media not being able to report unbiasedly or of the government not allowing members of the media who were willing to do so to report at all, there were also examples of media members asking hard-hitting questions, reporting real stories, and investigating items which the government may have found unpleasant.

Just over a year after the embarrassment to the media that was the 1993 election campaign coverage, that same media "looked far more robust" in their reporting and analysis of the Chechnya crisis. In a situation that was very reminiscent of the one that took place some thirty years earlier, the Russian government "now faced a problem not unlike that faced by the United States government during the Vietnam War" (Benn 474). The government, which just a year earlier had displayed mastery in its manipulation of the media and in circumventing the laws which protected media freedoms, now found itself "unable to impose a total news blackout and was constantly confronted by jounralists who refused to accept the official version of events" (Benn 474). Not unusual examples of press comments at the time were headlines in newspapers such as Izvestiya: "The Chechen war was lost in Moscow" or in the weekly Literaturnaya Gazeta: "Russians may be facing a second Afghanistan in Chechnya" (Benn 474). However, the key actor in the coverage of the Chechnya war was the role of non-state television, which is almost poetic in the fact that it was the television broadcasts a year earlier which stuck out as being so obviously biased in their reporting. For the first time, Russians were able to see televised images in their living rooms of their own "wounded soldiers being interviewed in field hospitals. Bloody corpses being pulled from a shotdown helicopter. Russian officers refusing to 
advance... women begging Russian soldiers not to shoot.” This was media reporting which was unprecedented, especially compared to the days of the Soviet Union and its heavy propaganda (Erlanger). In this instance, the NTV station in particular, founded in Moscow in 1993 and now with a potential audience of 100 million viewers in European Russia, played a particularly important part in telling the story of the crisis to the Russia citizens watching from their homes. Its news director, Oleg Dobrodeev, told a foreign visitor that for the first time there was "unanimous agreement about the stupidity and wrongness of official information” (Benn 475).

Obviously, when compared to the way that the Soviet Union had controlled the news during the Cold War to make sure that its citizens saw the USSR in a positive light, the fact that there were broadcasts being seen in Russian homes which showed the Chechnya crisis in a truly unflattering light was "a remarkable demonstration of journalistic independence" (Benn 475).

What is more important than almost anything else concerning the freedom of the media in post-Soviet Russia was its new found diversity. Where before there were only a handful of select media outlets, all mouthpieces for the Soviet state, in the years immediately following the collapse of the USSR there was essentially an explosion of news sources. Many of these quickly became financially independent and a viable means of business, which prompted more and more individuals to give it a try professionally. Although, there was not complete independence from the state which still controlled the paper and printing industries as well as the majority of the newspaper distribution networks, this control was much weaker than ever previously seen in the modern Russian state. As we shall see, after this incredible growth of news sources under Yetlsin, there would be a strong effort by Vladimir Putin to begin to pull these outlets back under the umbrella of the Kremlin once he rose to power.

In the wake of the fall of the Soviet Union it seemed as if a change from a strictly controlled media to an open and free media would be an inevitable outcome. The 1993 Constitution of the Russian Federation essentially said as much in its $29^{\text {th }}$ Article, which stated not only that "Everyone 
shall have the right to freedom of thought and speech" but also that "Propaganda or campaigning inciting social, racial, national or religious hatred and strife is impermissible. The propaganda of social, racial, national, religious or language superiority is forbidden" ("Russian Constitution"). Most important for the purposes of this study, the $5^{\text {th }}$ section of Article 29 stated that "The freedom of the mass media shall be guaranteed. Censorship shall be prohibited" ("Russian Constitution"). From the fall of the Soviet Union to the beginning of the $21^{\text {st }}$ century it seemed, as has been discussed, that this was the case. With the exception of a few moments of ambiguity there was largely a sense that the media within the Russian Federation was free from constraint and government control. However, around the turn of the century the media freedoms within the state also began to take a turn as the result of a set of events taking place at nearly the same time: Putin's Election, the Kursk submarine incident, and the sale of the Svyazinvest telecommunications company.

Vladimir Gusinsky was the founder of Most-Media which, initially, had Russian television station "NTV" as a subsidiary. NTV, in the years following the fall of the Soviet Union, was one of the leading examples of the new "free media" that had emerged in the Russian Federation. It was one of the few media outlets which provided critical coverage of the Russian Federation's performance during the Chechen War and was positively viewed by most international observers. Things began to change when, leading up to the Presidential Elections of 1996, NTV dramatically altered its position regarding the government and became outwardly very much in favor of incumbent President Boris Yeltsin (Herspring 60). After being so critical of the Chechen War and Yeltsin's leadership during it, this show of support was an abrupt change that was possibly necessary to Yeltsin, who had become very unpopular with the general public during the war. In 1995 Yeltsin was shown as having an $80 \%$ disapproval rating among the general population and it is believed that his decision to end the war was very much motivated by these sentiments (Herspring 59).

Following the election there was an expectation by Gusinsky that he would be receiving some 
sort of "return" on his investment in Yeltsin. He was hoping that he would be given control of the telecommunications company, Svyazinvest, as a sort of payment for his assistance during the election. He believed that this would happen in large part due to the way that the Russian Federation had handled the selling of corporations in the recent past, which essentially was a corrupt practice of selling businesses to oligarchs who had supported the government (Goldgeier and McFaul 215). However, instead of the expected simple transaction with Gusinsky the government opened up the sale of Svyazinvest for an auction. Both Gusinksy and others suspected that the government's auction had been rigged in a corrupt process that ended up with Vladamir Potanin being the winning bidder (Ames and Taibbi 223). The suspicion is that Potanin was tipped off by Deputy Prime Minister Anatoly Chubais on the bid of Gusinksy's group and thus was able to top it. The fact that Gusinsky was not given the opportunity to purchase Svyazinvest outright but also apparently denied the ability to win it in auction due to backhanded games of the administration left him incensed (Goldgeier and McFaul 215). ${ }^{1}$

Gusinksy, in the wake of this disappointing auction, once again changed his modus operandi in regards to the government and having recently been an outward supporter of Yeltsin, turned his considerable media muscle against the administration, particularly against Chubais (Goldgeier and McFaul 215). Gusinksy aimed the force of NTV squarely at the Yeltsin administration, becoming more and more critical of the government, in particular by looking at the "corruption within the Kremlin's inner circle" (Herspring 61). NTV provided for television media the lone critical view of the government and, much like it was during the first Chechen War, was the single critical view of Russia's renewed military involvement in Chechnya. However, unlike the first conflict in Chechnya, the second incarnation of the war was "much more popular than the first military intervention," and did not

$$
1
$$

It should be pointed out that the opinion the auction was unfair is not a unanimously accepted one. There are those, such as auction loser Mikhail Freedman of Alfa-Bank, who have said that the auction was "fair, and the bidder that made the highest bid won" (Ames and Taibbi 223). 
provide NTV with the security blanket of popular sentiment that was afforded it during its earlier critiques.

Those who were loyal to the Kremlin used this vulnerability of NTV to come at it with a public relations assault of their own, declaring it an "unpatriotic, pro-fascist, pro-Western organization," while the Kremlin itself stated that Gusinsky was "using his media power to settle old scores" ("Freedom of the Press"). As public support of NTV dwindled as the Second Chechen War grew in popularity, Vladimir Putin was able to utilize his direction of Russian forces in Chechnya to enhance his public image. In less than a year, due primarily to his involvement with the war and positive reporting from the majority of the Russian media, Putin was able to increase his electoral support from nearly zero, in August of 1999, to about fifty in March of the following year (Burnett 22). The war became a popular cause of support for Russian citizens following the bombing of apartments in Russia that lead to over three hundred Russian lives lost (Burnett 22). Following the bombings public support for Putin soared in the months leading up to the election. ${ }^{2}$ After the election of Putin as President of the Russian Federation the drama between NTV and the Kremlin came to a head.

In the early months of Putin's presidency the conflict between the government and the concept of free media began in earnest. Putin "repeatedly pledged allegiance to freedom of the press and readily admitted that freedom of the press is absolutely necessary in a modern society, and that [Russia]...must ensure that the press is free" (Herspring 60). Despite these claims, Putin by his actions gave the impression that he was strongly in support of state control of the mass media and "his campaign against privately owned national television was launched within days of his inauguration" (Wegren and Herspring 110). In his first annual address to parliament he stated that "Sometimes [the media] turn into means of mass disinformation and tools of struggle against the state" (Herspring 62).

In January of 2000, the Kremlin really began to flex its muscles to expand to its influence over

2 It should be noted that there are those, including Russian expert David Satter, who believe that the bombings were part of a conspiracy to guarantee that Putin would succeed Yeltsin (Satter). 
media. This was exemplified by the actions that were taken against Alexander Babitsky. Babitsky, a correspondent for Radio Liberty (an offshoot of Radio Free Europe) was, like the NTV station, one of the few voices that spoke critically of Russia in its involvement in the second Chechen War. In midJanuary Babitsky was "detained by Russian troops...and was accused of being part of a guerrilla unit" (Karon). According to Jean-Paul Marthoz, the European press director of Human Rights Watch, "Babitsky's arrest and continued detention [was] yet another attempt to muzzle independent coverage of the Chechnya conflict. Russia [was] arresting journalists for not having an accreditation which Russian authorities refuse[d] to provide them in the first place" (“Arrest"). Some argue that the Kremlin was making an example out of Babitsky, using his capture and subsequent beatings as a warning to other journalists to refrain from issuing reports criticizing the Kremlin. This was a new take on "censorship" that was different that the overt practices of the Soviet regime which determined what was and wasn't permissible to publish or broadcast. This was more of an indirect, soft censorship. For example, it has been reported that Putin "prefers to threaten broadcasters with the revocation of their licenses rather than to force them to shut down their operations" (Captain 9). This method is different from the outright banning of certain publications, but makes it difficult for media outlets that are frowned upon by the government.

Similar to the case of Babitsky, in which a "warning" was given to a journalist who reported in ways that didn't support the Kremlin's causes, was a much more serious incident involving Anna Politkovskaya. As troubling as the incident involving Babitsky was, the situation involving Politkovskaya was much worse. Politkovskaya was known as one of the "most prominent" reporters covering the Second Chechen War and often provided critical commentary of the Russian Federation's actions (Cornell 252). Putin made it clear in the past that he wasn't a fan of reporters who made public their criticisms of the Russian Federation's actions in the Chechen War, having said that there was only one truth about the Chechen War (the government's version) and that any alternative views expressed 
publicly could be considered treasonable (Lipman 121). At the entrance to her apartment building, Politkovskaya was murdered in an act that is widely considered to be an assassination and that many feel was intended to send a message to others. According to the deputy director of the Moscow of Human Rights Watch, Tanya Lokshina, the message sent by the government through the Politkovskaya killing was very straightforward. She believes it is a "very clear signal to Russian civil society: those who dare criticize the government can be killed, with their killers practically guaranteed impunity" (Lokshina). Now, it should be stated that no direct connection has been made between the Russian government and the Politkovskaya shooting; suspect, however, is the coincidental timing (Putin's birthday, October $7^{\text {th }}$ ) and a seeming lack of motivation by the government in punishing those directly responsible for the murder. The original trial of the three men accused in the Politkovskaya killing resulted in their acquittal. This result was eventually overturned only to have the possibility of a second trial left in a state of limbo due to a lack of direct evidence and a large amount of bureaucratic red tape, leaving the prospects of a future retrial slim. It should be mentioned that Politkovskaya was, before her death, a witness in a court case against Ramzan Kadyrov (Rykovtseva). Kadyrov, known to be both pro-Russian and Kremlin supported, is a warlord in Chechnya that had earlier threatened Politkovskaya after an interview that became hostile (Jeffries 264, Russel 87). In a posthumously published collection of her notes and writings Politkovskaya says that the Kremlin has fostered a "baby dragon" in Kadyrov, which it now needs to keep feeding "to stop him from setting everything on fire" (Politkovskaya, Snow, $\&$ Tait).

As Putin's time in power grew longer, his actual power within Russia became stronger. While Putin would give lip service to the ideas of a free media and the importance of freedom of the press, his actions would prove that he believed in this only when it proved beneficial for the Kremlin. As Sergei Yastrezhembsky, a Kremlin spokesman, told to the Kommersan newspaper, "When the nation mobilizes its forces to achieve some task, that imposes obligations on everyone, including the media" (Forest 
340). According to the Committee to Protect Journalists, Putin "believes unambiguously that the role of the press is to generate public support for state initiatives, and not public discussion of them" (“Babitsky's 'Crime' and Punishment”).

While it can be argued that incidents involving a couple of individual reporters who proved to be especially aggravating annoyances to the Kremlin could just be coincidences, or possibly the result of their own aggressive journalism without any involvement from the Kremlin, what happened with the NTV television station proves that this line of thinking may be slightly naive. As was previously mentioned, NTV was a subsidiary of Vladimir Gusinsky's Media-Most. Gusinsky, known for his "enormous temper" and having been previously disappointed by the outcome of the Svyazinvest company sale, publicly made the Kremlin the target of his vitriol (Jack 136). Gusinsky is even reported to have said, in regards to Putin, that he would "destroy him" politically (Jack 136).

The actions of Gusinsky following his failure to acquire Svyazinyest angered Putin. This is a fact that should not be underappreciated, as it was Putin's anger, in combination with Gusinsky's antiKremlin stance, that really motivated Putin to move aggressively against NTV. While what happened could be likened to the extinguishing of a pestering annoyance, it was also a matter of revenge (Jack 137). Regardless, the result was increased government control over the media.

The forceful takeover of the NTV television station by the Russian government was justified by Putin when he said in reference to NTV that "the television has people who have been destroying the state for ten years" (Traynor). Instead of applying tactics that may have been used against individual journalists to an entire television station, Putin demonstrated his own PR savvy by resisting the urge to “simply shut down NTV by force" (Herspring 122). At the time NTV was experiencing financial troubles which made it easy for the state-supported gas company, Gazprom, to “[oust] Gasinsky's representatives at a shareholders' meeting” and, at least on paper, take control of NTV (Jack 135). It should be noted that these financial troubles were very much Kremlin-related. For example, the Video- 
International advertising agency decided to end its exclusive contract with NTV. Video-International founder, Mikhail Lesin, was a "close Kremlin ally, heading the Ministry for the Press, Radio and Television Broadcasting, and Mass Communications.” This forced NTV to invest in its own advertising division so as not to lose too much revenue (Belin 34). With NTV's corporate finances firmly tilted towards Gazprom (and, therefore, towards the Kremlin), all that remained was making sure the station itself was actually under control of Gazprom. This was accomplished during the pre-dawn hours of Easter Sunday, 2001. With Gasinsky being held under house arrest in Spain (in large part the work of Moscow, convincing him to leave Russia after jailing him for three days), there was essentially no resistance to Gazprom's takeover of the building, escorted by a newly hired and armed security team (Baker and Glasser 78, 83). A few of the employees walked out, quitting their jobs with the station, but it was essentially a quiet takeover. However, the incident did strike a chord with various journalists throughout the state who viewed it very much as an infringement on the freedoms of the press. They included Vladimir Pozner, one of Russia's best known journalists who said, "Maybe television is not a place where decent people can work. I was appalled by the way the takeover happened. I don't want to work for either Trotsky or Stalin." He continued by saying "I have a painful impression that NTV has been murdered. It was undoubtedly a hostile takeover that had been approved by the authorities" (Jack 133).

The takeover was essentially given Putin's tacit consent, saying that "I do not think that I, under these conditions, have the right to interfere in this conflict between different economic players." The NTV case spoke volumes for how Putin planned on running things while he was in power and also "sent a clear warning to other media owners and editors to bring them into line" (Jack 133). Such incidents are examples of the shadow of censorship that looms in Russia despite the post-Soviet laws promising that the state's infringement on media freedom would be a thing of the past. Incidents like those previously mentioned often provide enough incentive for editors, owners, and producers to keep 
a tighter leash on their reporters, an indirect form of control resulting in self-censorship and a general environment of censorship. This leads to complaints from journalists that "founders" (essentially ownership representatives) are interfering in their work in an effort to "influence editorial policy" (Simons 47). 


\section{Comparisons in Control}

\section{International Strategies Regarding Internet Control}

The fact that the internet is so different from previously established media is one of the reasons that it needs to be treated differently in terms of controlling its content and the ways in which it can be used and manipulated. It is important to know that there is no universally accepted approach by governments around the world in their strategies for handling any problems that may arise for them as a direct result of the internet.

Not only did the turning of the century essentially usher in the beginning of the Vladimir Putin era in the Russian Federation, but it marked the approximate beginning of a new era in the United States (and essentially the world), the Post- 9/11 era. In a post-September $11^{\text {th }}$ global society there was a general feeling, especially in the immediate time after the 2001 attack, that there needed to be certain changes made in order to improve the general safety of all. In nearly every public setting a larger emphasis was placed on security. However, initially there was not much attention paid to cyber security. Only in recent years has the United States government begun looking deeper into ways in which it could exert its influence over cyberspace, not just in the realm of security, but also in other areas of interest for the government.

In addition to the variety of reasons that a government may be interested in shaping some of the content that is "broadcast" on the internet, there are also a number of ways in which a government could have an impact in what is or is not displayed on the internet. There are a variety of methods that are available for governments to use as well as different rationales that can be employed for spinning state intervention and involvement.

It should be pointed out that in the United States, as of 2010, there were over 239,232,863 internet users based on polling done by Internet World Stats, using the definition of "internet user" as 
someone who has "available access to an Internet Connection point," and also has "the basic knowledge required to use web technology," bringing the proportion of the population that qualifies as "internet users" to $77.3 \%$ ("World Internet Usage"). This is a number that has risen over $100 \%$ since the turn of the century and, as with anything, increased public use brings with it increased government attention. There are many concerns in the United States about the constitutional protections that are offered by the First Amendment, how they relate to the Internet and any attempts by the government to regulate what is on the internet, and what can and cannot be published on the internet.

One such effort to begin to determine what is and what is not protected by the First Amendment on the internet is the Supreme Court case United States v. American Library Association, 539 U.S. 194, 214 (2003). In this case the Supreme Court found that the United States was able to implement in public schools and libraries content blocking software that would be able to prevent access to certain banned materials.

This case has influenced what has happened in other forms of media such as television and print; it established a precedent for the government to reference if it needs to further tighten the measures to control the content on the internet. In theory the state's aim was to protect children, and very few people would doubt that children need protection from web predators and pornographers. The desire to protect children is an almost universal idea that allows the government to pass a measure of censorship on the internet and have it planted there like a seed to be grown and harvested if such an occasion ever occurs where legal precedence might be needed.

Of course, the main fear is about direct censorship, the government directly stepping in and preventing the public from having access to certain thoughts and ideas. It was originally felt that this was little threat to the internet, compared to other media, due to the fluid nature of the medium itself. There is a mindset which argues that the internet is resistant to direct regulation of speakers and listeners due to the fact that it is more of a "complex chain of connection," rather than a source leading 
directly to its market (Kreimer 11). However, the popular notion that the internet is too large and unwieldy to be controlled completely by a government is no longer a certain truth, as recent events have shown. There are those that feel that "with current technology, the standard methods of Internet filtering - blacklist and block - are not as effective at identifying and limiting content hosted via Web 2.0 applications, diminishing the impact of regulatory action of this sort within the jurisdiction of states." This means Web 2.0, or essentially social networking sites, should be the target of the governments plans because the internet as a whole is just too complicated to attempt to place under control (Faris, Wang, and Palfrey 165). In January of 2011 the concept of what a government could or could not do in terms of its regulation of the internet was fundamentally shaken to its core as Hosni Mubarak essentially pulled the plug on Egyptian internet. In an unprecedented move Mubarak was able to reduce internet traffic in Egypt by over 90\% almost instantaneously. It has always been possible for governments to shut down certain parts of the internet, especially around the time of elections and protests, but there has never been such a dramatic strike against it before, leaving some experts to claim that it was "unprecedented in scope and scale" (Ritchel).

Obviously, there was international outrage at the shutdown of the Egyptian internet, especially from NGOs such as Read Write Web and Reporters Without Borders, but the fact remains that Mubarak was able to do something that many assumed was impossible: almost completely shut down the internet in an entire country. It goes without saying that the ability to do this in a country such as the United States could have unprecedented ramifications. That's why it should be noted that there are those in the United States government who wish to afford the President of the United States just such a power. Before going into the feasibility of such a plan being pulled off effectively in the United States, a country with an internet grid many times larger and much more complicated than the internet system that is in place in Egypt, let's look at what exactly is being proposed.

There are those that say that a "kill switch" for the internet, under the President's control, is a 
necessary precaution to have available in the event of a technological attack on the United States. As Connecticut Senator Joesph Lieberman has said, "We cannot afford to wait for a cyber 9/11 before our government finally realizes the importance of protecting our digital resources" (McCullah). A bill has been repeatedly introduced into Congress attempting to provide the President with the power to "shut down portions of the internet" and/or to "restrict access to certain Web sites or types of content" (McCullah). There have been plenty of public relations games that have come out of the proposed bill and its rewrites, such as an addition to the bill that states specifically that the President does not have "the authority to shut down the internet." The bill's detractors find this to be nothing more than a meaningless addition to the bill due to the fact that even without a complete shutdown of internet access in the United States there could be selective shutdowns and specifically targeted censoring. There has even been a name change to the bill, from "Protecting Cyberspace as a National Asset Act" to something that seems less aggressive and more protective of internet/speech freedoms and less preventative, "Cybersecurity and Internet Freedom Act" (McCullah).

Congressman Lieberman has sent mixed messages in his defense of the bill, not wanting to alienate those who think that it is a violation of their personal freedoms, yet still wanting to show that he feels that it is a defensive mechanism that the President of the United States simply must have at his/her disposal in the future. In an interview conducted after the President's State of the Union address, Lieberman was asked to comment on whether this bill would be granting the President the "absolute power to shut down freedom of speech." Lieberman brushed off the concerns with the following statement:

No way, and total misinformation. I don't know whether people are intentionally pedaling misinformation. Here is the fact. Cyber war is going on in some sense right now. Our civilian infrastructure, the Internet that runs the electric grid, the telecommunications grid, transportation, all the rest is constantly being probed by nation states, by some terrorist groups, by organized criminal gangs. 
And we need this capacity in a time of war. We need the capacity for the president to say, Internet service provider, we've got to disconnect the American Internet from all traffic coming in from another foreign country, or we've got to put a patch on this part of it.

The president will never take over -- the government should never take over the Internet. Listen, we've consulted, Senator Collins and I, who are proposing this bill, with civil liberties and privacy experts. This is a matter of national security. A cyber attack on America can do as much or more damage today by incapacitating our banks, our communications, our finance, our transportation, as a conventional war attack.

And the president, in catastrophic cases -- not going to do it every day, not going to take it over. So I say to my friends on the Internet, relax... ("Interviews with Senators Lieberman, Murkowski").

Despite the fact that Lieberman gave an almost flippant tone to his rebuttal of the dangers of this bill and his reassertion that it is a necessary matter of state defense, he did little in denying the initial worries that the government would have the authority to shut down the internet (or shut down considerable access to the internet) at its discretion. The sentiment of "the freedom of media and speech is necessary... unless it goes against the interests of the government" echoes back to the speeches made by Putin in his early days in office when he repeatedly stated the importance of freedom of media. It is a difficult task to determine how likely it is for a government to be attacked through the internet, on such a large scale, that it would necessitate doing something that would so seriously disrupt the lives of the country's citizens. As Professor Ronald Deibert has said "a government that chooses to tamper with the internet - let alone shut it off - incurs potentially serious diplomatic, political, and economic costs. Citizens and businesses have become increasingly dependent on Internet communication and transactions" (Richtel).

However, it should be noted that a government's complete shutdown of the internet is essentially a "worst case scenario", though, as has been shown by Egypt and Libya earlier this year, a scenario that is not out of the realm of possibilities. That said, there are more immediately pressing 
circumstances under which the United States government affects the content that its citizens are allowed to both distribute and ingest online. Instead of such a large scale shutdown, or the targeting of specific individuals, there are other options that governments, including the United States, have at their disposal when trying to shape the message that is being broadcast on the internet. This option is not aimed at the audience or those who make the message themselves, but at those who distribute the access: "Rather than attacking speakers or listeners directly, governments have sought to enlist private actors within the chain as proxy censors to control the flow of information" (Kreimer 11). Of course, that is not to say that the subject of internet security and looking at private actors within the internet access chain are mutually exclusive from one another. In fact, the very nature of the internet, its inherent global quality, could be forcing governments to look towards private actors as a means of security.

It has been said by the United States State Department that "advancing Internet freedom around the world is central to [its] foreign policy," and as part of an agenda to ensure cyber security. There has been a proposed movement by the United States' Federal Communications Commission that is pushing for "network neutrality" or "open Internet" (a more in-depth look at network neutrality will be addressed later in this thesis) which would "[forbid] Internet Service Providers (ISPs), such as AT\&T, Comcast, and Verizon, from interfering with the online choices of users" and effectively prevent them from being able to block, blacklist, or discriminate against any variety of websites or online technologies (Ammori 55). However, the government would also wish to provide a loophole to be able to allow those same ISPs to prevent internet access to technologies, groups, or individuals that could be deemed security threats by the government by "blocking or discriminating against them" which starts a slippery slope. Who or what should be deemed a legitimate security threat? Who should be in charge of making this distinction? Is that a responsibility/power that ISPs should be given?

In the United States, more so than in any of the other states that are closely looked at in this 
study, there is a belief that its citizens should be immune from censorship and given the right to say whatever they wish, without consequence or penalty, due to the First Amendment of the United States constitution. However, there are those that believe that the First Amendment, while important, "provide[s] the purely commercial aspirates of corporate America with a constitutional shield from justified public criticism." If there is no "principled critique of the market and the types of censorship it systematically imposes," the sphere of open public discussion may be severely diminished, rather than expanded or even protected (Ammori 57)

That said, the internet issue in the United States runs deeper than just ISPs playing a role in the American cyber security. There are also issues of government pressure on internet companies and individuals, especially in the wake of the WikiLeaks controversy. WikiLeaks is a self proclaimed "not-for-profit media organization" which states that its goal is to "bring important news and information to the public" and to "provide a ... secure and anonymous way for sources to leak information to our journalists" (“About”). However, not everyone is pleased with the information that WikiLeaks distributes, including the United States government. After a series of leaked cables were released in 2010, the US government reacted by putting pressure on businesses that had associated with WikiLeaks in the past. This includes the efforts by the previously mentioned Senator Lieberman who issued a statement that "call[s] on any other company or organization that is hosting WikiLeaks to immediately terminate its relationship with them," adding that the information being distributed by WikiLeaks has been "illegally seized." "No responsible company - whether American or foreign should assist WikiLeaks in its efforts to disseminate these stolen materials" (Tsotsis, "Sen. Joe Lieberman”). After being questioned by Senator Lieberman regarding its business relationship with WikiLeaks, Amazon.com Inc. (which had been hosting WikiLeaks' site on its servers) shut down the servers that the website was being hosted on, knocking WikiLeaks off line for several hours, before they were able to move their site to a Swedish host (Arthur and Halliday). After being removed from 
the Amazon servers WikiLeaks released a statement via their twitter account stating that if Amazon.com Inc. was "so uncomfortable with the first amendment, they should get out of the business of selling books" (“Twitter - WikiLeaks”).

While most agree that legally this act was not a violation of the First Amendment of the US Constitution, because Amazon.com Inc is a private company, many feel that the act (and in particular the pressure that was placed on the company by the US Government) is a bad omen for the future. Electronic Frontier Foundation's lawyer, Kevin Bankston, stated that the incident, while not illegal, "certainly implicates first amendment rights to the extent that web hosts may, based on direct or informal pressure, limit the materials the American public has a First Amendment right to access" (MacAskill).

Amazon wasn't the only company to feel the pressure by the United States government for involvement with the information distributor WikiLeaks, though Amazon claims that the government's pressure was not the cause for the dissolution of its relationship with WikiLeaks. Many companies, including financial companies that were handling donations to WikiLeaks, have outright halted their relationships in light of government pressure. Companies including Visa, MasterCard, PostFinance, and PayPal have stopped their connections after pressure. PayPal's vice-president of platform, Osama Bedier, said that "the state department, the US government basically, wrote a letter saying that the WikiLeaks' activities were deemed illegal in the United States and as a result our policy group had to make the decision of suspending the account. We... comply with the regulations around the world, making sure that we protect our brand" (Tsotsis "Paypal VP").

There were those in the political establishment who felt that this clearly wasn't a matter of freedom of speech, but rather a matter of treason. For example Congressman Mike Rogers stated that Private Bradley Manning, a source of many leaked documents, should be charged with treason and "If they won't charge him with treason, they ought to charge him with murder," adding that "the death 
penalty clearly should be considered here," and that "we know for a fact that people will likely be killed because of this information" (The Telegraph). Vice President Joe Biden has stated that Julian Assange, the founder of WikiLeaks, is "a high-tech terrorist" ("Biden Makes Case"). However, there are many outside of the government who believe that there are no grounds to prosecute against WikiLeaks, including Harvard Law Professor Yochai Benkler, who says that "the Constitution's First Amendment simply does not permit prosecution of WikiLeaks. It is not, as a matter of law, sustainable to treat WikiLeaks or Assange any differently than the New York Times and its reporters" (Benkler). Benkler says that even though the individual companies that acted against Wikileaks are private, "it is impossible to ignore the role that a diffuse, even if uncoordinated set of acts by government officals... played in triggering the commercial services denial of service attack" (Benkler 3). He adds the fact that a public statement of a public official pressuring a company to disassociate with a journalistic organization "suggests a deep vulnerability of the checks imposed by the first amendment in the context of a public sphere built entirely of privately-owned infrastructure" (Benkler 24).

In January of 2011, the Department of Justice sent a subpoena to microblogging platform Twitter, requesting "information about users suspected of links with WikiLeaks," which led the NGO Reporters Without Borders to release a statement saying that the subpeona "constitutes a serious breach of personal data protection by the Obama administration, which has repeatedly proclaimed its support for online free expression" (Jlidi). The NGO added that "the publication of information by WikiLeaks and five associated newspapers was a journalistic activity protected by the First Amendment, even if the information was classified" (Jlidi).

Furthermore, there was an incident where a government official, via the school's Dean, was able to tell students at Columbia University's School of International and Public Affairs that they should "NOT post links to these documents [wikileaks] nor make comments on social media sites such 
as Facebook or through Twitter," and that "engaging in these activities would call into question [the student's] ability to deal with confidential information, which is part of most positions with the federal government" (Mackey).

There is also the issue of net neutrality, which is an issue of great importance when one considers the methods by which the Russian government handled television media, and how similar techniques could be applied to the Russian internet. According to the non-profit Free Press, net neutrality is an idea designed to make sure "that Internet sevice prviders may not discriminate between different kinds of content and applications online" ("Frequently"). This idea is further explained by Sir Tim Berners-Lee, the credited inventor of the internet, who says that net neutrality is an idea to ensure that "If I pay to connect to the Net with a certain quality of service, and you pay to connect with that or greater quality of service, then we can communicate at that level" (Berners-Lee). What this amounts to is that ISPs would have to treat all pieces of information equally to better ensure that certain items or pieces of information do not get unjustly discriminated against by the ISPs. There are schools of thought that believe without net neutrality, eventually ISPs will start selling packages of available websites (in much the same way that cable companies package TV channel packages). The real issue about net neutrality is control, control of the internet and the services it provides, and while on the surface this seems like a debate on whether or not the average internet user in America should have to buy a website package in order to go to ESPN.com or CNN.com, the issue that is really at the center of this debate is control of information. As Sir Berners-Lee said, "Control of information is hugely powerful. In the US the threat is that companies control what I can access for commercial reasosns" (Berners-Lee). He also added that "In China, control is by the government for political reasons" (Berners-Lee).

While the United States government works on trying to tame the internet in ways that are both beneficial for the state and also satisfactory to the general public (or at least spun in a manner so that 
these security measures seem reasonable enough for the average American), there is a method of controlling the internet that is on the opposite end of the spectrum and also needs to be considered when looking at the potential options that are open to the Russian Federation in the future as the society becomes more "wired." That is the method employed by the People's Republic of China. China, more so than maybe any other state, utilizes third parties in its efforts to control the internet and the messages that it enables Chinese citizens to see. It should also be noted that China, as has been reported for the Russian Federation, has allegedly been outwardly aggressive with its internet technologies and manipulations. Unlike the cyber attacks that were brought against Estonia in the late 2000's, the attacks that China has been accused of are against a non-state actor, the internet behemoth Google. However, before discussing how China has been aggressive towards third parties in relation to the internet, it should be pointed out how China utilizes third parties for its internet manipulations.

At the moment, in order for companies to conduct business in the People's Republic of China, they must agree to the government's rules regarding the "self-censoring [of] any information the government deems inappropriate" (Dann and Haddow 219). It should be noted that there is a key factor in the China situation, making it slightly different than those situations in the United States and the Russian Federation, and that is the human rights vs. legal rights controversy. Both the USA and Russia have laws that to varying degrees protect against censorship and when there are instances of censorship there are immediate murky legal waters that must be navigated. With the Chinese government openly in full control of the freedoms that are allowed to media/speech/expression, it is necessary to look at what is really at stake, not just legally, with regards to internet censorship, manipulation, and controls.

Is Internet Access a human right? Asking that question puts even more importance on the issues of internet censorship, more so than taking away the ability to find sports scores, stream movies 
and listen to music; is controlling access to the internet a violation of a basic human right? There is a growing movement that says that it is. An international poll conducted by the BBC in 2010 found that $79 \%$ of web users believe that internet access should be viewed as a fundamental human right. For the record, China came in $8^{\text {th }}$ internationally for states whose citizens believe internet access is a right, ahead of the United States. Over 71\% of Russians polled felt that they could not cope without the internet. However, there are more reasons to grant credence to this line of thinking than the polling of citizens. For example, recently in response to a plan by President Sarkozy to put France at the forefront of the effort to stop internet piracy, the Constitutional Council (France's highest court) determined that access to the internet is a basic human right and that "free access to public communication services online” is protected by the Declaration of Human Rights (Kirkpatrick).

As information regulation is nothing if not political, the fact that many view internet access to be a human right provides many rounds of public relations ammunition for politicians wishing to criticize foreign governments. For instance, in response to the PRC's restrictions on access to the internet within its borders, United States Secretary of State Hilary Clinton has gone on the offensive against the Chinese government in an attempt to build good will with its citizens, saying that the United States is "supporting the development of new tools that enable citizens to exercise their right of free expression by circumventing politically motivated censorship," and that the U.S. will "make sure that those tools get to people who need them" (Applebaum). She also made a political symbolic offering of goodwill by urging the Chinese government to change its stance on internet censorship so that it doesn't risk "walling themselves off from the progress of the next century" (Applebaum). Clinton's talk is not just all bluster as it is her goal to rally US corporations behind her quest for improved internet freedom, which could pose some issues for China. According to Russel Moses, a political analyst based in China, "Chinese officials have managed for many years to distinguish between American companies and American policies," but adds that "the new line from the United 
States suggests that this is going to be tougher now" (Ford). So, to understand the importance of this development it is necessary to understand the methods that China utilizes to maintain control on internet content within its borders.

While the United States concerns itself with finding a balance between trying to control, or at the very least tame, an independent internet and all the thoughts and ideas that come with it, the Chinese experience may be more relevant when trying to anticipate what Russia's next moves might be. This is especially true since Russia has begun talks with China concerning the very subject of internet controls. With a notoriously stringent system of censorship, China's government "blocks web sites that discuss the Dalai Lama, the 1989 crackdown on Tienanmen Square protesters, Falun Gong, the banned spiritual movement" and many other items (The New York Times). One interesting word that is being censored, and has been since the end of 2010, is the English word for "freedom," which speaks volumes about what messages the government is trying to control and how they aren't only filtering content in the Chinese language (The New York Times).

As has been shown by Russia in recent years and is expected to continue over the next several, China's internet development has grown exponentially over a very short time period. China's slow start to internet integration was in many ways an effect of the economic reforms and "open-door" policy that took place in the late 1970s/early 1980s, with internet development at any level not coming until nearly ten years later (Liang 109). China started its venture into the internet when several academics, who were being supported by foreign partners, started to look into the internet for academic purposes in the late 1980s. In 1994 China became the $71^{\text {st }}$ nation to become registered on the internet when it set up its first dedicated line to the computer network and received the domain name CN (Liang 109).

The first networks that China had connected to the internet included the China Academic Network, China Research Network, and Institute of High Energy Physics Network, which were 
reflective of the fact that in the early days of its involvement China used the internet primarily as an academic tool, in the pursuit of knowledge and its exchange. Some might find it to be a rather ironic fact considering the current condition of the internet within the country (Liang 109). It didn't take long for the potential importance and impact the internet could have, not just in the academic sphere, but also in the economic world, to be realized by the Chinese government. Once this significance was realized, paired with the relatively recent economic reforms enacted by the government, China put a sizable amount of muscle behind the idea of internet expansion. This lead to a rapid increase in the number of citizens who were able to access the internet (in many ways similar to the rapid increase that is currently occuring in Russia) with a few thousand citizens being considered internet users in the mid-1990s and that number growing to over 2 million by 1998 and exponentially increasing to over 100 million by 2005 and to nearly 300 million at the end of 2008 (Liang 109) (Freedom House 68). By the end of 2009 the government operated China Internet Network Information Center reported that there were over 384 million Chinese internet users with over 53 million joining in the last six months of the year (Qiang 48). This growth in the number of internet users led not only to China passing the United States of America as the "largest Internet user of the world," but also made it something that simply could not be ignored by the Chinese government. The government that understood the importance of the internet and global interconnectivity in terms of economic growth for China, also understood that a device that allowed for the free dispersal of information among over 300 million citizens could also serve as a convenient asset for those that wished to spread and promote ideas that the government frowned upon and believed to be detrimental to Chinese society. From the very beginning of the state's involvement with the information network the "Chinese government sought to assert its authority over the new medium" (Freedom House 68).

The concern over information that is available on the internet and its influence on the Chinese population is something that the government considered to be a valid and practical one. Chinese 
President Hu Jintao told party officials in 2007 that "Whether or not we can actively use and effectively manage the internet... will affect national cultural information, security, and the long-term stability of the state" (Scotton and Hachten 41).

These numbers showing the rapid growth of Chinese users are supported by other metrics for examining internet development, including the fact that the number of registered internet domain names in mainland China has increased from slightly more than 4000 in 1997, to almost two million in 2004, and near seventeen million in 2008. In that same timeframe the number of registered websites in China went from 4000 to close to three million (Liang 109). It is in no way lost on the Chinese government that there is an incredible amount of room for growth with only around $23 \%$ of the population being considered internet users (Liang 109). In addition, according to the Chinese government, in 2008 there were nearly 117 million citizens who were able to access the internet from their mobile phones, nearly doubling the number that were able to utilize such a service in 2007 (Freedom House 68).

Earlier in this thesis it was discussed how the Russian government has used its influence over multiple forms of media (including television and print media) in order to guide and shape the messages that those media are able to deliver to the general population. The influence that they have on these forms of media often comes from the fact that the majority of the individuals who own businesses and corporations that control such media are often connected to the Kremlin or at the very least considered to be easily swayed by the government for one reason or another, essentially having the government being, for lack of a better word, integrated into the ownership of the media. This kind of influence is also reflected in the Chinese government's involvement in the development of the Chinese internet. The fact that internet development in China was made possible because of the Chinese government's heavy investments in it in order to utilize it for economic development, as part of a "state-centric strategy for comprehensive informationization," has allowed the government to be 
intertwined within the fabric of the country's internet infrastructure from the very beginning (Liang 110). The fact that the Chinese government has operated under a single-party system and has been intergrated in the development of the internet from day one has allowed its regulation (and censorship) of the internet to "[evolve] into a comprehensive, multidimensional system that governs internet infrastructure, commercial, and social use as well as legal domains "(Liang 110).

The Chinese government uses a multilayered approach to censorship, making it better able to prevent individuals from working around it (though it is not immune to such possibilities as will be discussed later). There is a basic foundation of information filtering and content control that has been in place since 2003 with other layers and techniques working in addition to that basic infrastructure (Freedom House 68). While the current foundation has been in place, more or less, for slightly less than a decade, there have been strategic moves by the government to monitor, control, and filter online activities since the late $80 \mathrm{~s}$. These multiple levels of censorship include "a complex web of regulations, surveillance, imprisonment, propaganda, and the blockade of hundreds of thousands of international websites at the national- gateway level," (Qiang 49). This blockade is part of a government program known as the Golden Shield but is commonly known as the Great Firewall of China.

China is more overt with its censorship agenda than either the United States or Russia and has a system in place within the state in order to properly delegate censorship objectives. China has the Central Propaganda Department that makes sure that content within the media and Chinese culture, in general, follow the ideological line set forth by the government. There is also a department that monitors news websites within the country (State Council Information Office). These branches issue directives to local authorities that then carry these tasks out and, in some cases, "issue their own censorship directives and fine, threaten, or shut down media outlets" that report information to the public that government officials would prefer to have kept quiet (Qiang 50). These agencies provide a 
human monitoring element in their goal of content control which is helpful in the pursuit of selfcensoring by citizens, which will be discussed in more depth later, but they are aided greatly by the technological devices that are in place.

One of the methods used by the government for controlling the content of the Chinese internet is IP blocking. Traffic on the internet carries with it information called an IP Packet. The IP packet contains an IP number telling where the information's destination is and a different IP number that tells where the information is originating from, essentially a return address for the internet ("The Great Firewall"). Between the time it leaves its original address and reaches its destination, the information has to go through a series of checkpoints (known as routers) that check the origin IP number before passing it along to the next router. If a router is programmed not to pass along information for or from a certain IP number, all of the computers that are programmed to work through this router will be unable to interact with computers having this IP address. This practice is known as IP blocking and is one of the methods utilized by the Chinese government to block content coming from known objectionable sources (“About Filtering”). Research conducted by the Global Internet Freedom Consortium, an organization that promotes a censorship free internet, found that computers within China that were attempting to reach blocked websites would eventually have their IP packet sent through the international-level router (202.97.33.2) at which point the IP packet would be dropped by the router ("The Great Firewall"). This method of censorship requires the list of blocked IP's to be updated regularly and requires censors to monitor the content of websites in order to determine if they need to be added to the blocked IP list or not.

Another method of content control that is used by the Chinese government are TCP connection cut-offs. A TCP is "responsible for verifying the correct delivery of data from client to server," looking for errors and lost data and signaling for a retransmission of data until it arrives at its destination ("Introduction to TCP"). Logical data connections are established using TCPs when users 
visit websites, allowing for the the two parties to have a three-part connection, wrapping information in TCP segments(“The Great Firewall”). Much like IP packets, these segments will also use routers to go from one destination to another. When programmed to do so, routers can send out TCP packets to destinations that contain commands such as RESET which will halt the flow of information ("The Great Firewall"). These routers are programmed to analyze TCP packets flowing through them and search the information contained within for a "list of pre-defined keywords" ("The Great Firewall"). Once one of these terms is detected the router sends RESET commands to both the source and the destination and, in addition, will remember the connection that was established between the two computers and will block the connection for a little more than two minutes, to prevent automatic attempts to reestablish the connection, after which the connection can once again be made assuming that no blacklisted terms are used ("The Great Firewall"). The terms that are blacklisted, known as "keywords," can be found in the URL (a type of filtering that will be addressed later) or within the information that is being transferred. This type of filtering is referred to as HTML Response-Keyword Filtering. This can cause websites that contain an offending term, but are otherwise noncontroversial, to not be viewable by the intended audience (Zitterain and Edelman 77).

The Chinese government, in establishing what made certain words blacklisted and what was permissible, came up with nine categories of terms that the government did not want to be seeping into the Chinese internet. The categories include information that (1) "is contrary to basic prinicples that are laid down in the Constitution, laws, or administration regulations;" (2) "is seditious to the ruling regime of the state or the system of socialism;" (3) "subverts state power or sabotages the unity of the state;" (4) "incites ethnic hostility or racial discrimination, or disrupts racial unity;" (5) "rumors or disrupts social order;" (6) “propagates feudal superstitions; disseminates obscenity, pornography, or gambling; incites violence, murder, or terror; instigates others to commit offenses;" (7) "publicly insults or defames others;" (8) "harms the reputation or interests of the state;" (9) "has content 
prohibited by laws or administrative regulations" (Hughes and Wacker 62). This gives the Chinese government a seemingly unlimited reach when considering what content it can deem to be inappropriate for the Chinese internet.

Another technical method that the government uses in its effort to filter the information accessible on the internet is called URL hijacking. This method of censorship involves the government disrupting the efforts of internet users from reaching certain websites by having the user be sent to different web addresses (often non-existent ones). This is different from a practice known as URL redirection, which is often done with proxies in order to direct many URLS to the same "core" site. With URL hijacking the computer does not recognize that it is hijacked. In addition, unlike URLs designed to send the user to another site, when a URL is hijacked the contents of its page can be checked before the redirection takes place (Yu and Tseng 5). This works because whenever a website's address (its URL) is entered into the address bar of the browser that is being used, the user's computer has to take this web address and convert it into a corresponding IP address so that it can send the previously discussed IP packets. In order to do this the user's computer needs to issue a query to a Domain Name Service (DNS) resolver that will then, eventually, issue a query to the "authortative DNS server" of the destination URL ("The Great Firewall"). China's filtering system is set up in such a way that it is able to make the computers of users trying to access URLs containing a banned keyword think that they are actually going to the correct address when, in fact, they are being led to a false location. The location they are taken to the IP address: 64.33.88.161 ("The Great Firewall"). Visiting that IP address takes you to a standard error screen which simply states that the page cannot load properly and gives no signal that it is the incorrect page or that there was any censorship taking place.

However, the way that the keyword filtering works, in terms of banned keywords found within the data packages, means that it is not $100 \%$ without fail as there are occasions when websites, with nothing else about them that would lead to censorship beside the use of a banned word within their 
content, can slip past the filters if the keyword would happen to get split into separate data segments and, therefore, able to slip past the filters unscathed. However, this is an infrequent occurrence and, for all intents and purposes, whenever a banned word is used within the content of a site that particular site will find itself banned within the boundaries of China.

Of course, there are many ways to intentionally get around the government's internet censorship. These methods include the use of "proxy servers, private emails" and search manipulation, but even then there are often ebbs and flows to the government's filtering efficiency and sometimes the censorship is more difficult to bypass than at other times (Liang 111). This is due, in large part, to the fact that there isn't a consistent standard for what is found to be in violation of the guidelines that the government uses to determine if a keyword is to be blacklisted or not.

However, the technical firewalls and filters are not the only devices being used to monitor the content that is able to be accessed on the internet within the borders of China. The Chinese government has also been able to gain the assistance of businesses (by either applying pressure on them or coming to a monetary agreement) in their pursuit of an internet environment that better suits it, and also have been able to place pressure on individuals who otherwise might be participating in the distribution of the sort of information that is being weeded out. As an example, after the year 2000 there was a priority set, through government regulation, concerning the delegation of police power to non-state sectors and "instituting self-regulation" (Liang 111). Many business owners feel that selfregulation is their only viable option when considering the pressure placed on them by the government and the high penalties that often come along with violating the desires of the government. Many businesses in China find themselves caving to logistics of self-censorship at the expense of freedom of information, like those involved with the Internet Society of China, which issued in the early 2000s a “public pledge on self-discipline for China Internet Industry," which was signed by over 100 Chinese businesses. This pledge includes articles stating that those companies who signed will refrain "from 
producing, posting, or disseminating pernicious information that may jeopardize state security and disrupt social stability, contravene laws and regulations and spread superstition and obscenity. Monitor the information publicized by users on websites according to law and remove the harmful information promptly" [emphasis added]. They will also refrain from "establishing links to the websites that contain harmful information so as to ensure that the content of the network information is lawful and healthy" (Tambini et al. 297). The pledge also states that business will encourage "people to use the internet in an ethical way, to enhance the internet ethical sense and reject the spread of harmful information on the internet," and adds that "If the internet service provider discovers information which is inconsistent with the law on its website, it will remove it" (Tambini et al. 297).

However, as strong as the "Golden Shield" that China's Ministry of Information Industry uses to control content might be, it is not infallible. The Chinese government realizes this and this is why it was to turn to outside actors for assistance in monitoring and filtering the internet's information. Whereas China's Great Firewall is, for all intents and purposes, a technical marvel, it is the combination of the technical filtering and the self-censorship/corporation assistance that is really pertinent to the future filtering options possibly deployed by Russia. As stated previously in this study, since the fall of the Soviet Union the Kremlin has shown an increasing acceptance of the practice of utilizing its influence over corporations in order to streamline the message that is being delivered. This has primarily been done in relation to more traditional communication media such as newspapers and television stations but as usage of the internet continues to skyrocket, as it did in China, the Kremlin will be forced to take a stronger look at applying similar methods to the internet, much like Beijing already does.

For instance, Cisco, a technology corporation that specializes in internet routing equipment, has been named in a lawsuit that was filed in late May 2011 by members of the Chinese spiritual movement, Falun Gong (Markoff). The lawsuit states that Cisco has designed custom routing 
technology that not only allows China to continue in its Golden Shield censorship program, but also allows the Chinese state to locate and track those who are apparent members of Falun Gong, using the information that they transmit over the internet. ${ }^{3}$

Other tech companies that have felt the effects of China's desire to control internet content include Microsoft, whose search engine, Bing, had been shown in 2009 by the Global Internet Freedom Consortium to censor content, even within the United States, so that the information is more along the lines of the Chinese government's standards. Information entered into the search engine in English will show results similar to those shown when using the search engine, Google, however when certain phrases using Chinese language keywords, such as Charter 08 , there only were three results found (two of them being negative reactions and one being a non-existent link) ("Microsoft Censors").

Google itself has been the target of the Chinese government's muscle when it comes to content control on the internet. Cables released by WikiLeaks show that the Chinese government was behind what Google claims was "sophisticated cyber attack originiating from China" that hacked into the email accounts of multiple users, including human rights activists. The leaked cable states that the cyber attack was " $100 \%$ political" and Beijing has been "extremely concerned" with Google's product Google Earth and its high-resolution mapping software (BBC News - China Leadership). This took place after Google and Beijing had reached an uneasy agreement about the level of censorship that Google would have to accept. The attack was a large part of the reason that Google's co-founder, Sergey Brin, and the rest of Google's top executives determined that Google would no longer participate in censorship for the Chinese government (Levy 96). Google initially agreed to participate in the censorship as long as the information that they provided was more open than that provided elsewhere in China, but later decided to end its involvement in censorship. Google also withdrew its

3 The company released a statement saying that "Cisco does not operate networks in China or elsewhere, nor does Cisco customize our products in any way that would facilitate censorship or repression." Cisco has been tied to censorship in China since the early 2000's (Markoff). 
Chinese search engine, Google.cn, from China and instead redirected that link to Google.hk (Google's Hong Kong engine). In June of 2011, Google claimed that it prevented another cyber attack that was targeting the passwords of US government officials, Chinese human rights advocates, and journalists. Google said the attacks appeared to have originated in China. The Chinese Foreign Ministry denied the accusations and the official party newspaper claimed that Google was "deliberately pandering to negative Western perceptions of China," adding that "Google's accusations aimed at China are spurious, have ulterior motives, and bear malign intentions," and that "Google should not become overly embroiled in international political struggle, playing the role of a tool for political contention... for when the international winds shift direction, it may become sacrificed to politics and will be spurned by the marketplace" (Rowinski).

On a more selective basis, China is able to promote self-censorship by severely punishing individuals who use the internet to promote ideology and information that the government does not support, and currently imprisons more "cyber-dissidents" than any other country on the planet. They include Liu Xianbin, one of the signatories of the Charter 08 manifesto ${ }^{4}$ who has used the internet as a platform to post articles calling for reforms in China. He was sentenced in March of 2011 to 10 years in prison for "inciting subversion of state authority" ("Cyber-dissident Gets Heavy"). Zhang Jianhong, who had also posted articles promoting political reform onto the internet, was sentenced to six years in prison for the same crime and passed away in prison in January of 2011 ("Cyber-dissident Zhang Jianhong”).

In November of 2011, Cheng Jianping was sentenced to a year of "reeducation through work" for a sarcastic message posted to her twitter account concerning Chinese/Japanese relations. Tsering Woeser, a blogger who often comments about human rights for the Tibetan people had her twitter account hacked with content changed and deleted. Similarly incidents happened with her blog, along

4 Charter 08 is a "citizens' manifesto calling for constitutional democracy, human rights, rule of law, and tripartite separation of powers in government" within China (Link). 
with her facebook and gmail accounts ("Woman Sentenced to a Year"). Zhao Lianhai, the owner of a website that has been critical of the Sanlu milk powder sold in China, was sentenced for $2 \frac{1}{2}$ years for "inciting social unrest" (Burkitt). Tan Zuoren, an activist who has been critical of construction practices in China and their contribution to the 2008 earthquake deathtoll, was sentenced to five years in prison in 2010 for comments he made relating to Tiananmen Square, in emails (Reuters - "Chinese Advocate of Quake"). Huang Qi, another citizen critical of construction leading up to the 2008 earthquake, has been sentenced to three years in prison for "illegally possessing state secrets." Qi had served five years in prison previous to this for "inciting subversion" after publishing articles that were critical of the government on his website. He claims he was beaten badly while imprisoned (O'Neil). Other examples of such censorship include the story of Shi Tao, a thirty-seven year old business reporter who was sentenced to ten years in prison for sending a foreign website an email which included text of "a government warning that the return of a handful of dissidents who had witnessed the Tienanmen massacres might prove socially destabilizing" (Dowell 111). Human Rights Watch believes that in 2006 there were over sixty political prisoners who had been sentenced because they revealed information on the internet that the "government wanted kept quiet" (Dowell 111).

This chapter of the study has shown that the governments of the United States and China have become proficient at multiple methods of influence on individuals and businesses as part of their respective strategies in regards to controlling information that is distributed through the internet. Members of the United States government have demonstrated a willingness to use tactics of legal intimidation and public shaming to discourage businesses and individuals alike from participating in the spread of information on the internet that the government considers off-limits. The Chinese government, in addition to cyber censorship system that it utilizes, has also been linked to cyber attacks on individuals and corporations that have participated in the spreading of disallowed information. China has also been shown to take punitive action against individuals connected to 
information that the government wishes not to be shared. In the next chapter of this study will show the ways in which the Russian government has begun to use similar strategies from both countries, along with an open admission by the government that it is looking abroad at methods of internet control used by other countries. 


\section{$\underline{\text { Signs of the Coming Storm }}$}

\section{The Kremlin's Handling of the Internet}

Thus far in this thesis we have examined the relatively recent history of the Russian government's relationship with the media (since the fall of the Soviet Union) and have found that there has been a growing trend (especially since the rise to power of Vladimir Putin) of using Kremlin allies and intimidation tactics to shape the message of the media and the flow of information that is broadcast via more traditional means of information distribution (newspapers, television, etc.). What has also been discussed are the methods of that have been deployed by the United States and China for handling information found on the internet. This chapter of the thesis will examine the evolution of the Kremlin's method for handling information as it relates to the internet and the ways in which Russia has shown signs of borrowing monitoring/censoring ideas and technology from the United States and China. Showing how the Kremlin's approach has evolved along its own lines and also has picked up certain aspects of the techniques used by China and the United States will allow us to get a better idea of what can be expected from the Russian government. Especially in the coming years as the percentage of the Russian population that is able to access the internet continues to increase exponentially. The increase in Russian internet users had a slow start but has grown rapidly in recent years. Hovering between $7-15 \%$ of the population for the first part of the 2000 s, the percentage of internet users has rapidly risen in the past several years with various data showing up to $42 \%$ of the population was using the internet in 2010 and 47\% in February of 2011 ("National Issues Society," “World Internet Usage,” “At Least 90 Percent of Russians”). In 2010, Russian President Dmitry Medvedev stated at an International Economic Forum, that he predicted $60 \%$ of the population should have access to broadband internet by 2015 and gave the "rather ambitious [goal] to increase the number of Internet users in several years to the highest rate, perhaps of 90 people out of 100" ("At Least 90 
Percent of Russians").

The Russian government is able to use various methods, including the wording of state laws, to deny its practice of media censorship. Oftentimes the "effect of some of these laws is to drive the mechanisms of censorship internally - that is promote self-censorship (Simons 47). There are many laws that have been created in the twenty years since the fall of the Soviet Union which seem designed to curtail media criticisms and to shape public discourse in a manner benefiting the Kremlin, such as Articles 129, 130, and 319 of the Criminal Code which address "slander", "insult", and "insulting an authority," respectively (The Criminal Code of the Russian Federation).

These laws are important to keep in mind due to the fact that they open up many doorways and loopholes for the government to go through and utilize in controlling content that is allowed to reach the general population. It should be noted that in the modern age government tools used to shape messages that are dispersed via professional media outlets can also be turned towards the private sector. Thanks to social network sites average individuals have the ability to get their message out and have their voices heard by hundreds, if not thousands, and potentially even millions of people. This is a new wrinkle in modern media that can have far more impact than local outspoken citizens publishing and distributing zines ${ }^{5}$ with money from their own pocket. Once a person has access to a computer with an internet connection there is nearly an unlimited number of options available to them to get their voice heard, and most of them are free of charge. For example, according to Facebook founder, Mark Zuckerburg, as of June 2010 Facebook had over one million users in Russia and its membership numbers were "doubling every six months" (Barnett). Similarly the Russian search engine, Yandex, revealed that there at least 183,000 accounts on twitter that use Russian as their primarily language (this does not count the surely large number of people who primarily use English for their twitter accounts). Like Facebook, Twitter in Russia is seeing tremendous growth, having increased by over

5 Self published, independent magazines that often have the purpose of advancing social movements (Keating and Hartitai 26). 
twenty-six times from March of 2009 to March of 2010. Then, of course, there is the blogging platform Live Journal that, while it may seem a thing of the past in the United States, is the most popular platform in Russia. The ability that Live Journal gives its user base to get messages out to the public should not be underestimated. For instance, according to technology magazine Wired, live journal blogger Artemy Lebedev has a blog that has almost 60,000 "friends" and gets nearly 200,000 visitors per day (Kovalev). These blogs can be anything from places to discuss sports and day-to-day life or, as is the case with another LiveJournal celebrity blogger, Alexey Navalny, they could be blogs that campaign for anti-corruption (Kovalev).

The growing popularity of these platforms is not lost on the Kremlin. Nor is the influence that any given blogger could have on those that read his or her blog. The Kremlin realizes that for a certain percentage of the population, what they read on these blogs has just as much impact, if not more, than what they would read in the newspaper or watch on television. It is for this reason that the Kremlin has begun using the tool that was given to it by the Criminal Code on certain internet blogs. For instance there is the case of the twenty-eight year old musician, Savva Terentiev from Syktyvkar, who ran into trouble with authorities due to the content of one of his blog posts ("Russian Blogger Sentenced"). Terentiev was given a suspended jail sentence, being accused of "extremism" after he reportedly made a post (it has been removed from his website) that said that "Those who become cops are scum," and for allegedly saying that police officers should be put into a bonfire ("Russian Blogger Sentenced"). Terentiev ended up getting a one-year suspended term, having been convicted of "inciting hatred or enmity" ("Russian Blogger Sentenced").

This is not the only example of the Russian government aggressively going after those who use the internet to broadcast a message that might not be in line with what the Kremlin prefers. Whether it is about the government itself or about agents for the government, it appears that if the message proves to be an annoyance to the government, the Kremlin will have no reservation against swatting that 
annoyance away.

For example, former policeman Alexei Dymovsky has come under fire for messages that he has used the internet to help spread. Dymovsky made a series of video blogs in which he accused senior officers in the police department of corruption. After posting the videos to the internet Dymovsky was arrested and charged with "abuse of office" due to alleged "fraud committed by a person using his official position" ("Russia to prosecute"). However, Dymovsky does not feel that his arrest and prosecution is just, claiming it is retaliatory and that the charges brought against him are fabricated, saying "they want to silence me and gain revenge" for his videos which received over one million hits on YouTube. "The main thing is that the people of Russia have seen the light. Others will follow me," Dymovsky is quoted as saying. "You can't jail the whole of Russia. It's not 1937 anymore" ("Russia to prosecute").

There are also other instances of this sort of action being taken against bloggers by the government, such as the report of the arrest of the blogger Leonid Nikolaev who caused an uproar by creating videos criticizing the use of emergency vehicle lighting by government cars (Sidorenko). These arrests have created concern and dismay among those in the Russian blogger community about the potential for reducing their freedom of speech. There are many who feel that "in a country where the mainstream traditional media is deferential to authority," it is important to have a venue in which citizens can both speak their minds and be exposed to a variety of opinions that don't necessarily fall in line with the opinions of the Kremlin (Baldwin).

An example of the pressures that can be exerted by the government is demonstrated in case of the Russian company Yandex. Yandex is a the most prominent search engine in Russia and has been criticized for bending to the perceived censorship techniques of the Kremlin, despite its protestations to the contrary. In late 2009 Yandex altered the method in which its search results would show up to users. Yandex decided to change the system to "stop ranking or giving prominence to the most popular 
individual blog entries," which would be a blow against those looking to find bloggers who had opinions contrary to Kremlin politics (Osborn 1). The company said it came to this decision after realizing that it was becoming a popular tool for Russian radicals, an argument that came under fire by Russian bloggers who believe that this is part of a larger wave of censorship in Russia. According to popular Russian blogger, Maxim Sviridenkov, "People who think and feel differently from Putin and Medvedev should not be considered radicals." Sviridenkov continued by adding that the closing of the Yandex ratings "will undoubtedly become one of the decisive moments in killing free speech [within Russia]," (Osborn 1). Sviridenkov felt that the flames of censorship were encircling the internet as had happened to other forms of media in Russia, saying "In a situation where TV speaks exclusively about themes that suit the ruling regime, the blogosphere remains the only island of free speech" (Osborn).

It should be pointed out that according to internet watch sites DoSWatch and GlobalVoices, Sviridenkov's blog came under attack a few months after making those statements. His site was defaced and his archive content deleted ("Russian Blogger Maxim Sviridenkov"). The responsible party is currently unknown, though the Kremlin has a recent history of being connected (to various degrees) to internet attacks.

In 2009 the microblogging platform Twitter briefly was unavailable due to its servers being overwhelmed after a DoS attack took place against blogger Georgy Jakhaia, an economics professor who blogs under the aalias Cyxymu and is often critical of the Kremlin ("Georgian blogger"). Occuring at the same time were attacks against Jakhaia's Facebook, LiveJournal, and Google accounts. "No one else but Russia was interested in destroying my site," Jakhaia said after the attacks (“Georgian blogger"). According to Max Kelly, the chief security officer at Facebook "It was a simultaneous attack across a number of properties targeting him to keep his voice from being heard" (Mills).

There have also been legal consequences for those who have used the internet as a means of voicing their issues with the Kremlin. Alexei Navalny is the operator of a "wikileaks-style website" 
known as Rospil.info where he has set out to track corruption within the Russian government. Navalny is also a former advisor to Nikita Belykh, the current Governor of Kirov and a former opposition politician (Bratersky). According to the website they have found a reported total of over $\$ 58$ million in "alleged government fraud" with Navalny himself publishing a leaked Audit report of " $\$ 4$ billion fraud by former executives at Russia's state-owned pipeline company, Transneft” (“Charges Brought Against Russia's Chief Whistleblower"). Recently Navalny has come under legal pressure, being charged with "inflicting damage by means of deceit" in May of 2011. According to Navalny he is being falsely charged due to his criticisms of the Kremlin and the fact that he has acted against Prime Minister Putin, particularly earlier in the year when he referred to Putin's party, United Russia, as a "party of swindlers and cheats" (Bratersky). Yandex has also become involved in the matter after giving the Russian Federal Security Service information concerning individuals who used Yandex's payment system for donating money to the Rospil organization after receiving an official order that Navalny believes came directly from the Kremlin (“Charges Brought Against Russia's Chief Whistleblower"). In addition to having financial information delivered to the FSS, many Russian bloggers have received phone calls asking about their association with Navalny and why they had given money. Many believe that these calls came from a member of the pro-Kremlin group, Nashi, posing as a journalist (Bratersky). Nashi is a youth organization that is "run by the Kremlin and sponsored by its associated businesses," has over 120,000 members, and its "unthinking nationalism and glorification of Putin" have critics viewing it as the next Komsomol or giving it the name of Putinjugend - in reference to the Hitlerjugend, "Hitler Youth" (Lucas 79).

This was by no means the first involvement of the Nashi organization in connection with incidents of cyber censorship involving the Kremlin. In April of 2011 the blogging platform LiveJournal, the "country's main platform for uncensored political discussion," was the victim of a cyber strike. The Cyrillic alphabet portion of the website, which is used by over 4 million Russian 
citizens, was struck by multiple DoS attacks that left the site inaccessible in Russia on two separate occasions (Odynova). According to the development director of SUP (the platform's owner), Ilya Dronov, "The attack targeted dozens of top bloggers and communities," and believes that the strike was an attempt to make the website "disappear as a platform" (Odynova). There were many fingers pointed at the Kremlin, such as those of former director of SUP, Anton Nossik, who stated that the massive attack was beyond the means of a small group of vandals and required significant "financial support." Nossik hinted that the Nashi group was the likely candidate behind the attack, possibly working under the orders of "influential Kremlin advisor Vladislav Surkov" (Antonova). Nossik has stated that there is a "total correspondence in goals and times between public acts by Surkov's proteges and the attacks of the cyber criminals" (Antonova). The previously mentioned Alexei Navalny stated that the attacks on the blogging platform were part of the Kremlin's "counter-propoganda plan" that it was initiating in anticipation of the upcoming Duma and Presidential elections (Odynova). According to Russian opposition figure Boris Nemstov, "LiveJournal is really a zone of freedom, and the attack on it is preparation for parliamentary and presidential elections. It is pure politics," he noted, adding that "Hardly anyone could have done this other than the security services" (Antonova). There are even some, like Russian political analyst Mikhail Delyagin, who believe that the attack on LiveJournal was "a rehearsal of some 'X Hour' to break communication among the active part of society."

The idea of these attacks serving as practice for a future attack was shared by more than one individual. Andrei Soldatov, the head of the Agentura.ru think-tank, stated that he feels the attack was "a test drive during a very important year to see if it's possible to close down websites, in particular social networking sites in case of demonstrations" (Grove).

The LiveJournal attacks aren't the largest cyber assault that Nashi has been connected with. In 2007 there was a coordinated cyber attack against Estonia. This took place following tensions arising from the relocation of a Soviet military memorial. According to leaked cables (via WikiLeaks) the 
Estonian government feels the "probing nature of the attacks on specific government and strategic private sector targets through the use of anonymous proxies ${ }^{6}$ fit the modus operandi of the Putin regime testing a new 'weapon"' (WikiLeaks. "Cable 07TALLINN366."). The cable stated that while Konstantin Koloskokov, a leader of the Nashi organization, had taken responsibility for some of the cyber attacks, Estonia viewed him as a fall man. "Koloskokov is window dressing, a convenient set-up by the real perpetrators," and that the attacks were "extremely sophisticated; beyond the technical abilities of an amateur," and were done so quickly that they are "still uncertain how it was done" (WikiLeaks, "Cable 07TALLINN366.").

There have also been certain recent instances, much like there have been for years in China, of individuals being jailed for the comments they make online. Such is the case of blogger Irek Murtazin, who made posts concerning the health of Tatarstan politician Mintimer Shaimiyev and was sentenced to 21 months in prison. Murtazin was the former Press Secretary for Shaimiyev (Whitmore).

Then there are also the more "old school" methods of intimidation used against those who write and distribute information online that shines an unflattering light on the Kremlin. In much the same way that there have been physical (sometimes deadly) attacks on those working in the newspaper and television industry, as the internet has become an ever growing part of Russian society and its media culture, so too has risen the number of physical altercations that have taken place involving individuals with an online presence who are critical of the Russian government. Such was the case with journalist and blogger Oleg Kashin, who was beaten so badly in late 2010 that he had to be placed into a medically induced coma with the assault being considered an attempted murder (BBC. "Leading Russian"). The editor of the newspaper Kommersant, where Kashin works, stated that "It's clear that the people who did this did not like what he says and writes" (BBC, "Leading

6 An anonymous proxy is a server that "sits" between the user's computer and the internet. It prevents websites that are being visited by the user from determining the user's IP address (Salomon 236). 
Russian").

Despite the fact that the Russian prosecutor general will be overseeing the case and President Medvedev himself has said that "the criminals must be found and punished," there are many who are skeptical about finding the perpetrators (if the government is truly unaware of their identity). These skeptics include Russian affairs analyst Damien McGuiness who feels that this case, and its resolution, can be viewed as a sort of litmus test for how seriously the Kremlin is in regards to preventing journalist intimidation (BBC, "Leading Russian”).

In late September 2008, Magomed Yevloyev, the owner of the website Ingushetiya.ru (a website that was often critical of the leaders of the Russian republic of Ingushetia) was killed under suspicious circumstances. According to reports by the authorities in the area Yevloyev was accidentally shot in the head while he was resisting arrest (CNN, "Kremlin Critic Shot"). The deputy editor of Ingushetiya.ru, Ruslan Khautiyev, claims that Yevloyev arrived on a plane from Moscow that was also being occupied by regional President Murat Zyazikov (of whom Yevloyev had been critical of in the past). Upon landing, local police boarded the plane and detained Yevloyev, taking him away in a car, and then leaving him on the side of the road with a gunshot wound in the head (CNN. "Kremlin Critic Shot"). After the death of Yevloyev, Agnes Callamard, the Executive Director of Article 19, released a statement saying that "The death of Magomed Yevloyev can only contribute to the environment of fear and intimidation in which Russian oppositional media are forced to operate." Article 19 is a human rights NGO that works to "protect and promote the right to freedom of expression," taking its name from Article 19 of the Universal Declaration of Human Rights ("The Universal Declaration of Human Rights"). The police officer who had shot Yevloyev, Ibragim Yevloyev (no relation), was given a sentence of two years supervision and was allowed to continue working as a police officer. He was shot to death in a seemingly unrelated incident in 2010 (“Convicted Killer”). 
In August of 2008 Roza Malsagova, the editor-in-chief of Ingushetia.ru, had numerous criminal charges brought against her at once, causing her to leave the country and request political asylum in France. Her lawyer stated that the cases brought against her "were undoubtedly connected to her activities at the website" ("Russian Society Under Control").

Another such incident is that of Mikhail Afanasyev, the editor of Novy Fokus - an online magazine, who was assaulted by two unidentified attackers and suffered head injuries in addition to a broken jaw. This attack came a month after a defamation lawsuit was brought against Afanasyev following his publication of a blog post that was critical of the government's reaction to a power plant explosion in Khakassia (UNHCR). As part of the investigation of the charges, Afanasyev had his phone, computer, and apartment keys confiscated by authorities, although the case against him was dismissed shortly before the assault. Joel Simon, the Executive Director of the Committee to Protect Journalists, agreed that this case is suspicious, saying "That a journalist whom authorities tried to prosecute for his reporting is now being attacked in broad daylight suggests official indifference or worse" (UNHCR).

That isn't to say that intimidation tactics and perceived cyber assaults are the only methods that the Kremlin is able to use in its effort to monitor content on the internet. In March of 2011 Russia's federal supervisory agency for communications, Roskomnadzor, announced a software design contest for developers. The software requested will be used to "monitor online media outlets for extremest content," would be able to "check text, audio and video posted on online media websites," and would be able to track down content including "public calls to commit acts of terrorism, display of Nazi symbols or emblems, calls for the violent overthrow of constitutional order, violating the unity of Russia and inciting social, racial, national or religious strife (Reporters Without Borders, "Danger"). Obviously some of the targeted content is described rather broadly and could feasibly be applied to almost anything that the Kremlin finds offensive. This would allow Roskomnadzor the means to 
monitor content on the internet and would be a major step towards the ability to remove content that government officials deem troublesome or illegal. This isn't at the same level of sophistication as the Golden Shield used by the Chinese government, but it is similar in conception.

Unlike the Chinese government which is relatively overt in its desire for censorship and content control of the internet, the Kremlin is playing its hand much closer to the vest, represented by the mixed messages coming out of Moscow. On the one hand are statements made by the head of the Federal Security Service, Alexander Andreyechkin, discussing the need for access to encrypted communication providers. Andreyechkin said "different software is being distributed allowing the encryption of traffic: that is services including Gmail, Hotmail, and Skype," and added that "the uncontrolled use of these services could lead to a large-scale threat to Russian security" (Faulconbridge ). In response to the uproar that this idea caused, Igor Shchyogolev, Russia's Communications Minister, clarified that officials were researching how to regulate such technologies. Meanwhile, Putin's spokesman Dmitry Peskov commented that "There is no reason to be worried. The [Federal Security Service] has a point of view: there are other points of view, too. They are all going to be discussed" (Faulconbridge). Putin himself commented on the importance of the internet, saying that it is "a tool for solving social and administrative problems; it is an opportunity to communicate, to express yourself, it is a tool for improving your living standards." He continued, "The main resources are situated overseas, and this has been a source for concern for the special services but I personally think that it is not possible to restrict anything" ("Putin has played down"). In addition, President Medvedev commented about internet freedoms during the G8 Meeting that took place in late May, 2011, saying on his twitter account that "The net must be unrestricted, but a new way to protect copyrights is needed" (Medvedev). Of course, organizations such as the Committee to Protect Journalists have said that the Kremlin is "very successful in silencing independent voices without attracting international attention" (Ognianova and O'Brien). It should also be remembered, as was 
mentioned earlier in this study, that Putin had stressed the importance of freedom of the press at the beginning of his administration before tightening the noose around the traditional media.

This chapter of the study has shown the ways in which the Russian government has used a combination of intimidation and influence to try and control the content that is available on the country's internet. Much like the Chinese government, the Kremlin has been (indirectly) linked to multiple cyber attacks, including attacks against businesses and individuals that help in the dispersal of information and opinions that the government wishes to contain. It has been shown that if there are not direct incidents of the Kremlin issuing physical assaults on individuals promoting critical views, then at least it has given a silent consent to the actions through legal inaction. Much like in the United States, officials in the Russian government have issued statements intended to influence (and intimidate) individuals and companies that are involved in the spread of such information. It has been shown that the government publicly acknowledges the fact that it is looking abroad for potential strategies of managing the internet, specifically naming China. It can also be inferred that the Kremlin will also be looking at strategies that the US has deployed. Putin, as noted earlier, has acknowledged the United States dominance on the internet by stating that the majority of internet resources are overseas (from Russia). It has been noted that many officials within the Russian government have publicly stated that they are in favor of freedom of speech on the internet. It has also been shown that many of these same individuals are in favor of actions that run counter to this idea. These public declarations may be shallow due to the fact that, as shown previously in the study, the Russian government has a relatively recent history of promoting freedom of speech publicly and then putting into place methods to control it, such was the case with television. This chapter has shown that, utilizing many of the strategies used by the United States and China, the tightening of the Kremlin's grip on freedom of speech on the internet has already begun. 


\section{$\underline{\text { Conclusions }}$}

"It is enough to look at those resources that exist in the Russian Internet to see that there is no censorship there" says Dmitry Peskov, a spokesman for Prime Minister Vladimir Putin (Tvestkova and Bryanski). This was the common belief about the Russian internet for the past decade, that the government by and large kept its fingers out of the internet. For much of the past decade, this perspective rang relatively true. However, that is no longer the case. This is a turning point in the history of Russian media. What had become a relatively safe haven from government influence since the fall of the Soviet Union can now see the shadow of the Kremlin looming large overhead.

This is in line with the history of Moscow's interactions with the Russian media over the past twenty years and trends that have become visible once Vladimir Putin came into power. The arrests of bloggers, the assaults on internet journalists, the shutting down of websites, the suspicions that the largest search engine in Russia is censoring its search results to show fewer finds for political parties that are not aligned with the Kremlin, and general intimidation tactics used against individuals and corporations alike demonstrate that what once was a breeze of potential government influence over the internet has now become a rolling storm just about to break.

The events that have recently taken place in the Middle East are a reminder of what ultimately could happen if a government decides that it is are going to cut off its citizens from cyberspace. Looking at the actions of the United States show potential ways that the Russian government could subtly influence the internet. In particular, the potential ramifications of the net neutrality debate can be compared to how the Kremlin has been able to utilize corporations in other parts of the media, such as television, to great effect. The Chinese model is obviously a less subtle, yet still very realistic option that is available to the Russian Federation should it decide that it is in the best interest of the state to 
prevent certain items and concepts from finding their way to a large audience.

Earlier this month Ilya Ponomaryov, a member of the Duma Information Committee in the Russian Parliament, stated that Russia's "internet regulation is currently the most liberal in the world because we have none." That is a message that encourages optimism from those who hear it, for it surely signals that the government is not interested in internet censorship to any degree. However, Ponomaryov's words reveal more about the past than about the future, about a time when Russia was, in fact, in the early stages of internet regulation.

In the coming years the Kremlin will adopt certain technical practices from Chinese and certain legal circumventions and manipulations from the United States and incorporate them into its own effort of censoring the internet. It will not be as overtly oppressive as the Chinese "Great Firewall” because much of the damage will be done behind the scenes and with intimidation. In the short time that I have been working on this thesis, the signs of internet censorship have become more and more glaring. This is not to single Russia out, as all countries examined in this study are guilty of attempting to interfere with the freedom of ideas. However, with the number of Russian citizens on the internet increasing, it will be obvious to anyone who cares to look how tightly the grip of the Kremlin on the internet has become. 


\section{Bibliography}

"About." WikiLeaks. http://wikileaks.org/About.html (accessed June 8, 2011).

"About Filtering | OpenNet Initiative." ONI Home Page | OpenNet Initiative. http://opennet.net/aboutfiltering (accessed June 8, 2011).

Ames, Mark, and Matt Taibbi. The Exile: Sex, Drugs, and Libel in the New Russia. New York: Grove Press, 2000.

Ammori, Marv in. "'Security versus Freedom" on the Internet: Cybersecurity and Net Neutrality." SAIS Review 30, no. 2 (2010): 51-65.

Andrews, Josephine T.. When Majorities Fail: The Russian Parliament, 1990-1993. New York: Cambridge University Press, 2002.

Antonova, Maria. "Russian Bloggers Accuse Authorities of Cyberwar." PhysOrg.com - Science News, Technology, Physics, Nanotechnology, Space Science, Earth Science, Medicine. http://www.physorg.com/news/2011-04-russian-bloggers-accuse-authorities-cyberwar.html (accessed June 8, 2011).

Applebaum, Anne. "Internet Freedom: The State Department Can Combat Internet Censorship, but It's Not. What Gives? - By Anne Applebaum - Slate Magazine." Slate Magazine. http://www.slate.com/id/2290334 (accessed June 8, 2011).

"Arrest of Journalist, Blanket Media Restrictions on Chechnya Condemned | Human Rights Watch." Home | Human Rights Watch. http://www.hrw.org/en/node/66523 (accessed June 8, 2011). Arthur, Charles, and Josh Halliday. "WikiLeaks Fights to Stay Online after US company Withdraws Domain Name." The Guardian (London), December 3, 2010. http://www.guardian.co.uk/media/blog/2010/dec/03/wikileaks-knocked-off-net-dns-everydns (accessed March 23, 2011). 
"At least 90 percent of Russians Will Use Internet in Next Few Years - Medvedev | Russia | RIA Novosti." RIA Novosti. http://en.rian.ru/russia/20100618/159473876.html (accessed June 8, 2011).

"Babitsky's "Crime" and Punishment - Reports - Committee to Protect Journalists." Press Freedom Online - Committee to Protect Journalists. http://cpj.org/reports/2000/02/main.php (accessed February 28, 2000).

Baker, Peter, and Susan Glasser. Kremlin Rising: Vladimir Putin's Russia and the End of Revolution. New York: Scribner, 2005.

Baldwin, Chris. "Russian Blogger Sentenced for Extremist Post." Reuters UK. http://uk.reuters.com/article/2008/07/07/oukin-uk-russia-blogger-idUKL0757687320080707 (accessed March 21, 2011).

Barnett, Emma. "Mark Zuckerberg Confident that Facebook Will Reach One Billion Users." The Telegraph (London), June 23, 2010. telegraph.co.uk (accessed May 6, 2011).

Basok, Tanya , and Alexander Benifand. "Recent Political Developments in Russia and Four Types of Potential Refugees." Refuge 13, no. 7 (1993): 3-10.

BBC. "Leading Russian Reporter Oleg Kashin Attacked in Moscow." BBC - Homepage. http://www.bbc.co.uk/news/world-europe-11704036 (accessed May 5, 2011).

"BBC News - China Leadership 'Orchestrated Google Hacking'." BBC - Homepage. http://www.bbc.co.uk/news/mobile/world-asia-pacific-11920616 (accessed June 8, 2011).

"BBC News - Cyber Attack Forces WikiLeaks to Change Web Address." BBC - Homepage. http://www.bbc.co.uk/news/world-us-canada-11907641 (accessed June 8, 2011).

"Benkler Argues against Prosecution of WikiLeaks, Detailing Government and News Media "Overreaction"." Harvard Law School. http://www.law.harvard.edu/news/spotlight/intellectual- 
property/14_benkler-argues-against-prosecution-of-wikileaks.html (accessed June 8, 2011).

Benkler, Yochai . "A Free Irresponsible Press: Wikileaks and the Battle Over the Soul of the Networked Fourth Estate." Benkler.org. www.benkler.org/Benkler_Wikileaks_current.pdf (accessed May $23,2011)$.

Benn, David Wedgwood. "The Russian Media in Post-Soviet Conditions." Europe-Asia Studies 48, no. 3 (1996): 471-479. www.jstor.org (accessed January 10, 2011).

Berners-Lee, Tim. "Net Neutrality: This is Serious." MIT. dig.csail.mit.edu/breadcrumbs/node/114 (accessed March 23, 2011).

"Biden Makes Case For Assange As A 'High-Tech Terrorist'." Huffington Post. www.huffingtonpost.com/2010/12/19/joe-biden-wikileaks-assange-high-tech-terrorist (accessed April 4, 2011).

Bratersky, Alexander . "Navalny Targeted in Fraud." The Moscow Times, May 11, 2011. themoscowtimes.com (accessed May 26, 2011).

Burkitt, Laurie . "China's Spoiled Milk Protest." The Wall Street Journal (New York), November 22, 2010. wsj.com (accessed June 2, 2011).

Burrett, Tina. Television and Presidential Power in Putin's Russia . Milton Park, Abingdon, Oxon, England: Routledge, 2011.

Captain, Alex. "Putin's Unfree Press." Harvard International Review 25, no. 1 (2006). hir.harvard.edu (accessed January 24, 2011).

"Charges Brought against Russia's Chief Whistleblower." RIA Novosti. http://en.rian.ru/russia/20110510/163956882.html (accessed May 20, 2011).

CNN. "Kremlin Critic Shot Dead in Southern Russia - CNN." CNN World. http://articles.cnn.com/2008-09-01/world/russia.critic.killed_1_ingushetia-russian-republic- 
kremlin-backed?_s=PM:WORLD (accessed May 5, 2011).

Colton, Timothy J., and Jerry F. Hough. Growing Pains: Russian Democracy and the Election of 1993. Washington, DC: Brookings Institute Press, 1998.

"Convicted Killer Of Ingushetian Website Owner Shot Dead - Radio Free Europe / Radio Liberty ÂC 2011 ." Radio Free Europe / Radio Liberty - Free Media in Unfree Societies . http://www.rferl.org/content/Convicted_Killer_Of_Ingush_Website_Owner_Shot_Dead/21199 18.html (accessed May 5, 2011).

Cornell, Svante E.. "Russia's Gridlock in ChechnyaL Normalization or Deterioration?." In OSCE Yearbok 2004. Hamburg: Institute for Peace, 2004. 251-259.

"Cyber-Dissident Gets Heavy Jail Term After Unfair Trial." Reporters Without Borders. en.rsf.org/china-cyber-dissident-gets-heavy-jail-25-03-2011,39885.html (accessed April 25, 2011).

"Cyber-dissident Zhang Jianhong ("Li Hong") Gets Six Years in Prison - Reporters Without Borders." Reporters Without Borders. http://en.rsf.org/china-cyber-dissident-zhang-jianhong-li-19-032007,21354.html (accessed May 3, 2011).

Dann, Elijah, and Neil Haddow. "Just Doing Business or Doing Just Business: Google, Microsoft, Yahoo! and the Business of Censoring China's Internet." Journal of Business Ethics 79, no. 3 (2008): 219-234.

Dowell, William Thatcher. "The Internet, Censorship, and China." Georgetown Journal of International Affairs 7 (2006): 111.

Erlanger, Steven. "Russians Watch First War on Uncensored TV, to Yeltsin's Alarm." The New York Times, December 20, 1994, sec. World. nytimes.com (accessed March 1, 2011).

Faris, Robert, Stephanie Wang, and John Palfrey. "Censorship 2.0." Innovations (Spring 2008): 165- 
187.

Faulconbridge, Guy. "Russian Spy Agency Complains about Gmail, Skype." REUTERS.

http://reuters.com (accessed June 8, 2011).

Ford, Peter. "Clinton Bluntly Condemns China on Internet Censorship - CSMonitor.com." The

Christian Science Monitor - CSMonitor.com. http://www.csmonitor.com/World/Asia-

Pacific/2010/0121/Clinton-bluntly-condemns-China-on-Internet-censorship (accessed June 8, 2011).

Forest, James J. F.. Countering Terrorism and Insurgency in the 21st century: International

Perspectives. Westport, Conn.: Praeger Security International, 2007.

Freedom House. "China and the Internet - An Uphill Fight for Freedom." Harvard International Review Vol. 31, no. 2 (2009): 68.

"Freedom of the Press and the Future of Russia." NPR.

http://www.npr.org/programs/npc/2001/010503.vgusinsky.html (accessed May 3, 2001).

"Frequently Asked Questions | Save the Internet." Save the Internet | Join the fight for Internet

Freedom. http://savetheinternet.com/frequently-asked-questions (accessed June 8, 2011).

"Georgian Blogger Says Will not be Silenced." Business \& Financial News, Breaking US \&

International News | Reuters.com. http://reuters.com/article/2009/08/12/us-georgia-blogger-

idUSTRE57B32N20090812 (accessed June 8, 2011).

Gibbs, Joseph. Gorbachev's Glasnost the Soviet Media in the First Phase of pPerestroika. College

Station, Tex.: Texas A \& M University Press, 1999.

Gil-Robles, Alvaro. "Report by Mr. Alvaro Gil-Robles, Commissioner for Human Rights, on his Visits to the Russian Federation." Council of Europe. https://wcd.coe.int (accessed March 30, 2011).

Goldgeier, James M., and Michael McFaul. Power and Purpose: U.S. Policy Toward Russia After the 
Cold War. Washington, DC: Brookings Institution Press, 2003.

Goldstein, Steve. "The Age of the 'Un-Censor' in Gorbachev's USSR." Philadelphia Inquirer, May 1, 1989.

Grove, Thomas. "Russian Internet Attacks Stifle Political Dissent." Business \& Financial News, Breaking US \& International News, Reuters.com.

http://www.reuters.com/article/2011/04/13/us-russia-internet-idUSTRE73C1P520110413 (accessed May 20, 2011).

Herspring, Dale R. Putin's Russia: Past Imperfect, Future Uncertain. Lanham: Rowman \& Littlefield, 2003.

Hughes, Christopher R., and Gudrun Wacker. China and the Internet: Politics of the Digital Leap Forward. London: RoutledgeCurzon, 2003.

"Interviews With Senators Lieberman, Murkowski, Feinstein and Lugar." CNN.com - Breaking News, U.S., World, Weather, Entertainment \& Video News. http://ranscripts.cnn.com/TRANSCRIPTS/1006/20/sotu.01.html (accessed June 20, 2010).

"Introduction to TCP/IP ." Yale University. http://www.yale.edu/pclt/COMM/TCPIP.HTM (accessed June 8, 2011).

Jack, Andrew. Inside Putin's Russia: Can There Be Reform Without Democracy?. New York: Oxford University Press US, 2005.

Jeffries, Ian. Political Developments in Contemporary Russia . Milton Park, Abingdon, Oxon: Routledge, 2011.

Jlidi, Kacem. "The US Government Forcing Twitter to Hand Over Personal Data on Its Users. - Global Voices Advocacy." Global Voices Advocacy - Defending free speech online. http://advocacy.globalvoicesonline.org/2011/04/22/the-us-government-forcing-twitter-to-hand- 
over-personal-data-on-its-users/ (accessed June 8, 2011).

Karon, Tony . "Russia Declares War on the Media." time, February 9, 2000. time.com (accessed February 14, 2011).

Kirkpatrick, Marshall. " Is Internet Access a Fundamental Human Right? France's High Court Says Yes

." ReadWriteWeb - Web Apps, Web Technology Trends, Social Networking and Social Media.

http://www.readwriteweb.com/archives/is_internet_access_a_fundamental_human_right_franc. php (accessed June 8, 2011).

Kovalev, Alexey. "Why is LiveJournal still Massive in Russia? (Wired UK)." Wired.co.uk. Future Technology News and Reviews (Wired UK). http://wired.co.uk/news/archive/201102/04/livejournal-in-russia (accessed June 8, 2011).

Kreimer, Seth F.. "Censorship By Proxy: The First Amendment, Internet Intermediaries, and the Problem of the Weakest Link." University of Penn Law Review 155, no. 1 (2006): 11-101. LA Times (Los Angeles), "Soviet Union Bans Censorship, Grants Wide Freedom to Media ," June 13, 1990. http://articles.latimes.com/1990-06-13/news/mn-184_1_mass-media (accessed April 2, 2011).

Levy, Steven. "Inside Google's China Misfortune - Fortune Tech." Fortune Tech: Technology blogs, news and analysis from Fortune Magazine . http://tech.fortune.cnn.com/2011/04/15/googlesordeal-in-china (accessed June 8, 2011).

Levy, Steven. In the Plex: How Google Thinks, Works, and Shapes Our Lives. New York: Simon \& Schuster, 2011.

Liang, Bin. "Internet Development, Censorship, and Cyber Crimes in China." Journal of Contemporary Criminal Justice 26, no. 1 (2010): 103-120.

Light, Margot, and Vera Rich. "Notes of the Month: The Russian Elections and After." The World 
Today 50, no. 3 (1994): 42-44. jstor.org (accessed March 9, 2011).

Link, E. Perry. "Charter 08 in China, One Year On." Wall Street Journal (New York), December 8, 2009. online.wsj.com (accessed May 14, 2011).

Lipset, Seymour Martin. "Politics and Society in the USSR: A Traveller's Report." PS: Political Science and Politics 23, no. 1 (1990): 20-28. jstor.org (accessed July 15, 2011).

Lokshina, Tanya. "Anna Politkovskaya: No Justice | Human Rights Watch." Home | Human Rights Watch. http://www.hrw.org/en/news/2009/02/20/anna-politkovskaya-no-justice (accessed June 8, 2011).

Lucas, Edward. The New Cold War: Putin's Russia and the Threat to the West. New York: Palgrave Macmillan, 2009.

MacAskill, Ewen. "WikiLeaks Website Pulled by Amazon after US Political Pressure." The Guardian (London), December 2, 2010. guardian.co.uk (accessed February 4, 2011).

Mackey, Robert. "Don't Mention the Cables, Future Diplomats." The New York Times, December 4, 2010.

Markoff, John . "Suit Claims Cisco Helped China Pursue Falun Gong." The New York Times, May 22, 2011. nytimes.com (accessed June 1, 2011).

McCullagh, Declan. "Internet 'Kill Switch' Bill Gets a Makeover | Privacy Inc." Technology News CNET News. http://news.cnet.com/8301-31921_3-20033717-281.html (accessed June 26, 2011).

McNair, Brian. Glasnost, Perestroika, and the Soviet Media . London: Routledge, 1991.

McNair, Brian. "Media in Post-Soviet Russia: An Overview." European Journal of Communcation 9, no. 2 (1994): 115-135.

Medvedev, Dmitry. "Twitter - Dmitry Medvedev." Twitter. 
http://witter.com/\#!/MedvedevRussiaE/status/73798619240738816 (accessed June 4, 2011). Mickiewicz, Ellen Propper. Changing Channels: Television and The Struggle for Power in Russia. Durham, N.C.: Duke University Press, 1999.

"Microsoft Censors Web in U. S., Follows Chinese Regime Guidelines | Global Internet Freedom Consortium." Global Internet Freedom Consortium | . http://internetfreedom.org/Microsoft_Censors_Web_in_US_Follows_Chinese_Regime_Guideli nes (accessed June 8, 2011).

Mills, Elinor. "Twitter, Facebook Attack Targeted One User | InSecurity Complex - CNET News." Technology News - CNET News. http://news.cnet.com/8301-27080_3-10305200-245.html (accessed June 8, 2011).

"National Issues Society." Russia Votes.

http://www.russiavotes.org/national_issues/national_issues_society.php\#485 (accessed March 21, 2011).

"No Censorship, but There are Still Secrets." The Current Digest of the Russian Press 42, no. 31 (1990): 9 .

O'Neil, Daniel X.. "MediaShift Idea Lab . Huang Qi, Journalist, Formally Arrested | PBS." PBS: Public Broadcasting Service. http://pbs.org/idealab/2008/07/huang-qi-journalist-formallyarrested005.html (accessed June 8, 2011).

Odynova, Alexandra. "State Blamed in LiveJournal Attack." The Moscow Times, April 11, 2011. themoscowtimes.com (accessed May 13, 2011).

Ognianova, Nina, and Danny O'Brien. "Attacks on the Press 2010: Europe and Central Asia Analysis Committee to Protect Journalists." Press Freedom Online - Committee to Protect Journalists. http://www.cpj.org/2011/02/attacks-on-the-press-2010-europe-central-asia-analysis.php 
(accessed March 25, 2011).

Osborn, Andrew. "Russia's Yandex Search Engine Attacked for Abandoning Ranking." The Telegraph (London), November 4, 2009. telegraph.co.uk (accessed May 11, 2011).

Politkovskaya, Anna, Jon Snow, and Arch Tait. A Russian Diary. London: Vintage Books, 2008.

"Putin Has Played Down the Prospect of Internet Censorship in Russia." CNews - Russian IT Review. http://eng.cnews.ru/news/top/indexEn.shtml?2011/04/20/437379 (accessed May 15, 2011).

Qiang, Xiao. "The Battle for the Chinese Internet." Journal of Democracy 22, no. 2 (2011): 47-61. Reporters Without Borders. "Danger of Generalized Online Surveillance and Censorship." Center for International Media Assistance. http://cima.ned.org/danger-generalized-online-surveillanceand-censorship (accessed April 15, 2011).

Reuters. "Chinese Advocate of Quake Victims Sentenced Over E-Mails." New York Times, February 8, 2010.

Ritchel, Matt. "Egypt Cuts Off Most Internet and Cellphone Service." New York Times, January 28, 2011. nytimes (accessed March 14, 2011).

Russell, John. Chechnya - Russia's 'War on Terror'. London: Routledge, 2007.

Rowinski, Dan. "China Slams Google For Being a "Tool for Political Contention"." ReadWriteWeb Web Apps, Web Technology Trends, Social Networking and Social Media . http://www.readwriteweb.com/archives/china_slams_google_for_being_a_tool_for_political.p hp (accessed June 8, 2011).

Rubansteva, Marina. "The Fate of Literary Magazines: Gloomy Prediction is Coming True.." Current Digest of the Russian Press 44, no. 46 (1992): 32-33.

"Russia to Develop Software to Monitor News Websites for Extremist Content." Newswatch. http://www.newswatch.in/newsblog/9363 (accessed June 8, 2011). 
"Russia to Prosecute YouTube Police Whistleblower." Business News - Indian Stock Market, Stock Market News, Business \& Finance, Market Statistics | Reuters India. http://in.reuters.com/article/2009/12/28/us-russia-police-idINTRE5BR16720091228 (accessed June 8, 2011).

"Russian blogger Maxim Sviridenkov's Website Hacked - May 2010." DoSWatch. http://www.doswatch.org/2010/06/russian-blogger-maxim-sviridenkovs.html (accessed April $15,2011)$.

"Russian Blogger Sentenced for Comments on the Blog." EDRI | Digital Civil Rights in Europe. http://www.edri.org/edrigram/number6.14/russian-blogger-sentenced (accessed June 4, 2011).

"Russian Constitution SECTION ONE Chapter 2." Untitled Document.

http://www.departments.bucknell.edu/russian/const/ch2.html (accessed June 8, 2011).

"Russian Society Under Control." International federation for Human Rights. www.fidh.org/IMG/pdf/Russian_society_under_control.pdf (accessed April 29, 2011). Rykovtseva, Elena. "Old and New Razman ." Radio Svoboda. http://www.svobodanews.ru/content/transcript/266456.html (accessed July 18, 2011).

Salomon, David. Foundations of Computer Security. London: Springer, 2006.

Satter, David. "House Testimony 2007 ." Hudson Institute. www.hudson.org/files/publications/SatterHouseTestimony2007.pdf (accessed July 15, 2011).

Scotton, James Francis, and William A. Hachten. New Media for a New China. Malden, Mass.: WileyBlackwell, 2010.

Sidorenko, Alexey. "Russia: Blogger and Activist Arrested for Viral Video Â· Global Voices." Global Voices $\hat{A} \cdot$ Citizen media stories from around the world. http://globalvoicesonline.org/2010/05/28/russia-blogger-and-activist-arrested-for-viral-video/ 
(accessed May 28, 2010).

Simons, Greg. Mass Media and Modern Warfare: Reporting on the Russian War on Terrorism.

Farnham, England: Ashgate, 2010.

Steele, Jonathan, and Devid Hearst. "Yeltsin Crushes Revolt." The Guardian (London), October 5, 1993. www.guardian.co.uk (accessed February 15, 2011).

Swanson, David L., and Paolo Mancini. Politics, Media, and Modern Democracy: An International Study of Innovations in Electoral Campaigning and Their Consequences. New York: Praeger Publishers, 1996.

Tambini, Damian, Danilo Leonardi, and Christopher T. Marsden. Codifying Cyberspace: Communications Self-Regulation in the Age of Internet Convergence. London: Routledge, 2008.

The Criminal Code Of the Russian Federation. http://www.russian-criminal-code.com (accessed June 8, 2011).

"The Great Firewall Revealed." Global Internet Freedom Consortium. www.internetfreedom.org/files/WhitePaper/ChinaGreatFirewallRevealed.pdf (accessed May 7, 2011).

The New York Times, "Internet Censorship in China," March 22, 2010.

The Telegraph (London), "US Congressman Says Bradley Manning Should be Executed," August 4, 2010. telegraph.co.uk (accessed February 7, 2011).

"The Universal Declaration of Human Rights." The United Nations. http://www.un.org/en/documents/udhr/index.shtml (accessed February 20, 2011). Traynor, Ian. "Putin Aims Kursk Fury at Media." The Guardian (London), August 25, 2000. guardian.co.uk (accessed February 14, 2011). 
Tsotsis, Alexia. " Sen. Joe Lieberman: Amazon Has Pulled Hosting Services For WikiLeaks ." TechCrunch . http://www.techcrunch.com/2010/12/01/amazon/ (accessed June 8, 2011).

Tsotsis, Alexia. " PayPal VP On Blocking WikiLeaks: State Department Said It Was Illegal ." TechCrunch . http://techcrunch.com/2010/12/08/paypal-wikileaks/ (accessed June 8, 2011). Tsvetkova, Maria, and Gleb Bryanski. "Russia Looks Abroad for Web Laws, Including to China." Reuters.com. http://www.reuters.com/article/2011/04/16/us-russia-internetidUSTRE73F1NR20110416 (accessed May 5, 2011).

"Twitter - WikiLeaks." Twitter. http://twitter.com/\#!/wikileaks/status/10073870316863488 (accessed June 26, 2011).

"UNHCR." UNHCR. http://UNHCR.org (accessed June 8, 2011).

Wegren, Stephen K., and Dale R. Herspring. After Putin's Russia: Past Imperfect, Future Uncertain. 4th ed. Lanham, Md.: Rowman \& Littlefield Publishers, 2010.

Whitmore, Brian. "Shaimiyev's Long Reign Ends In Tatarstan - Radio Free Europe / Radio Liberty ÂC 2011 ." Radio Free Europe / Radio Liberty - Free Media in Unfree Societies . http://www.rferl.org/content/Shaimiyevs_Long_Reign_Ends_In_Tatarstan/1993356.html (accessed April 23, 2011).

WikiLeaks. "Cable 07TALLINN366." WikiLeaks. www.wikileaks.ch/cable/2007/06/07TALLINN366.html (accessed January 15, 2011).

WikiLeaks. "Twitter." Twitter. http://twitter.com/\#!/wikileaks/status/10073870316863488 (accessed May 10, 2011).

"Woman Sentenced to a Year's Forced Labour Over One Ironic Tweet." Reporters Without Borders. http://en.rsf.org/china-woman-sentenced-to-a-year-s-forced-24-11-2010,38886.html (accessed April 26, 2011). 
"World Internet Usage Statistics News and World Population Stats." Internet World Stats - Usage and Population Statistics. http://www.internetworldstats.com/stats.htm (accessed April 20, 2011). Yu, Hsiang-Fu, and Li-Ming Tseng. "Abnormal Web Usage Control by Proxy Strategies." National Central University - Distributed System Lab. 140.115.52.150/ yu/doc/IR-ProxyBreaker.pdf (accessed May 15, 2011).

Zittrain, Jonathan, and Benjamin Edelman. "Internet Filtering in China." IEEE Internet Computing March/April (2003): 70-77. 